\title{
Molecular genetics of attention-deficit/hyperactivity disorder: an overview
}

\author{
Tobias Banaschewski • Katja Becker • \\ Susann Scherag • Barbara Franke • \\ David Coghill
}

Received: 30 June 2009/ Accepted: 7 January 2010/Published online: 10 February 2010

(c) The Author(s) 2010. This article is published with open access at Springerlink.com

\begin{abstract}
As heritability is high in attention-deficit/ hyperactivity disorder (ADHD), genetic factors must play a significant role in the development and course of this disorder. In recent years a large number of studies on different candidate genes for ADHD have been published, most have focused on genes involved in the dopaminergic neurotransmission system, such as DRD4, DRD5, DAT1/
\end{abstract}

T. Banaschewski, K. Becker are joint first authors.

T. Banaschewski $(\bowtie)$

Department of Child and Adolescent Psychiatry

and Psychotherapy, Central Institute of Mental Health,

Postbox 122120, 68072 Mannheim, Germany

e-mail: Tobias.Banaschewski@zi-mannheim.de

K. Becker

Department of Child and Adolescent Psychiatry and Psychotherapy, Philipps-University of Marburg,

Hans-Sachs-Str. 6, 35039 Marburg, Germany

\section{S. Scherag}

Department of Child and Adolescent Psychiatry, University Duisburg-Essen, Virchowstr. 174,

45147 Essen, Germany

\section{B. Franke}

Department of Human Genetics, Radboud University Nijmegen Medical Center, PO Box 9101,

6500 HB Nijmegen, The Netherlands

\section{B. Franke}

Department of Psychiatry, Donders Institute for Brain, Cognition and Behaviour, Centre for Neuroscience, Radboud University Nijmegen Medical Center, PO Box 9101, 6500 HB Nijmegen, The Netherlands

D. Coghill

Division of Medical Sciences, Centre for Neuroscience (Psychiatry and Behaviour), University of Dundee, Dundee DD1 9SY, Scotland, UK
SLC6A3, DBH, DDC. Genes associated with the noradrenergic (such as NET1/SLC6A2, ADRA2A, ADRA2C) and serotonergic systems (such as 5-HTT/SLC6A4, HTR1B, HTR2A, TPH2) have also received considerable interest. Additional candidate genes related to neurotransmission and neuronal plasticity that have been studied less intensively include SNAP25, CHRNA4, NMDA, BDNF, NGF, NTF3, NTF4/5, GDNF. This review article provides an overview of these candidate gene studies, and summarizes findings from recently published genome-wide association studies (GWAS). GWAS is a relatively new tool that enables the identification of new ADHD genes in a hypothesis-free manner. Although these latter studies could be improved and need to be replicated they are starting to implicate processes like neuronal migration and cell adhesion and cell division as potentially important in the aetiology of ADHD and have suggested several new directions for future ADHD genetics studies.

Keywords Genetics - ADHD - Candidate gene studies . GWAS · Aetiology

\section{Introduction}

Attention-deficit/hyperactivity disorder (ADHD) is a common, clinically heterogeneous (in terms of comorbidities, gender effects, courses and outcomes), etiologically complex disorder characterized by early onset of age-inappropriate persistent and pervasive symptoms of inattention, hyperactivity, and impulsivity; twin and adoption studies show ADHD to be highly heritable, i.e., a heritability of around 0.76 [53]. Converging evidence from animal and human studies 
implicates the dysregulation of frontostriatal and frontocerebellar catecholaminergic circuits in the pathophysiology of ADHD [18]. In addition to prefrontal cortical areas, the basal ganglia, cerebellum, temporal and parietal cortex have been implicated in this condition [27, 141]. ADHD is associated with various neuropsychological alterations, such as deficits in vigilance-attention, cognitive control, namely executive function deficits, non-executive memory deficits, and motivation, namely delay aversion, as well as millisecond timing deficits, state regulation failures, intraindividual fluctuations in performance over time, and an altered sensitivity to stimulation [142, 163].

Up to now more than 1,800 publications, dealing with the genetics of ADHD, have been published and the following review will be representative and comprehensive, but not exhaustive, and is meant to give the reader an overview of current findings from genetic association studies of this disorder including both candidate gene studies and genome-wide association studies (GWAS). Studies on gene-environment interaction in ADHD are not included in this overview, but are reviewed in another article in this edition [186]. For the detection of small effects of individual genes, such as those likely to occur in ADHD, genetic association studies [144] are generally more suitable than genetic linkage analyses. However, population stratification differences between case and control samples can give rise to both type I and II errors if case and control samples are not well matched for ethnic background. Linkage studies have been extremely successful in elucidating the causes of monogenic disorders, but much less so in multifactorial disorders. ADHD linkage studies have identified a number of genetic loci (potentially) harbouring genes for ADHD and some chromosome regions such as 5p13, 14q12, and $17 \mathrm{p} 11$ have been indicated in multiple studies $[3,7,9,50,54$, $73,96,131,146]$. In the most recent meta-analysis of seven ADHD linkage studies, genome-wide significant linkage was only confirmed for one locus on chromosome 16 [196].

Until recently, association approaches were restricted to hypothesis-driven studies on candidate genes, as described in the following paragraphs. Such approaches are substantially influenced by the amount of existing knowledge regarding disease aetiology. Since this knowledge is still limited for ADHD, candidate gene based studies are likely to miss at least part of the genetic variance. Up to now, such studies can explain no more than $3-5 \%$ of the total genetic components of ADHD [98]. At the end of 2008, the first unbiased, hypothesis-free GWAS were published for ADHD, these will be reviewed below, after the candidate gene studies.

\section{Candidate gene approaches}

Genes belonging to the dopaminergic neurotransmission system-in particular the D4 dopamine receptor gene (DRD4) and the human dopamine transporter gene (DATl/ SLC6A3)-have been the most frequently investigated genes. In addition, genes of the noradrenergic and the serotonergic system have also been frequently studied. To date, individual gene variants have only shown small effects, rarely reaching an odds ratio of 1.3 (e.g. [53], a figure consistent with that obtained from meta-analyses of other complex traits [78].

\section{Dopaminergic system}

The effectiveness of methylphenidate, which acts by blocking the dopamine transporter, in ADHD treatment as well as the association of ADHD with those executive neuropsychological functions and frontostriatal pathways, that are dependent on an intact dopaminergic neurotransmission make the dopaminergic system the most intensively analyzed neurotransmitter system in ADHD [166].

\section{D4 dopamine receptor gene (DRD4)}

The association between ADHD and a 48 base-pair (48 bp) repeat polymorphism of exon III of the DRD4 geneencoding a receptor expressed primarily in the prefrontal cortex-is the strongest and most consistently replicated molecular genetic finding in ADHD. A meta-analysis of more than 30 studies found that the DRD4 7-repeat (DRD4-7r) allele increases the risk for ADHD, although this increase is only moderate with a pooled odds ratio of 1.34 [51, 98]. Importantly this finding was supported in Caucasian as well as several non-Caucasian populations [10, 17, 29, 66, 194]. In functional terms the DRD4 7repeat allele seems to alter the function of the encoded receptor by making it less sensitive to dopamine than the alternative alleles [5].

Studies of the cognitive correlates of the DRD4 7-repeat allele in ADHD have found mixed results. A hypothesis that the DRD4 7-repeat allele is particularly associated with inattentiveness rather than hyperactivity or impulsivity, has not yet been consistently confirmed [88, 120, 180]. Swanson et al. [165] were the first to report that carrier of at least one 7-repeat allele with ADHD did not display neuropsychological deficits. Moreover, the subgroup of probands with ADHD but without a 7-repeat allele (noncarriers) showed longer reaction times. Therefore, the 7repeat allele might be associated with behavioural features rather than cognitive deficits. These findings were confirmed by the results of Manor and colleagues [117] and 
Bellgrove and colleagues [16], who showed that children with ADHD with the 7-repeat allele exhibit better commission and omission scores and lower reaction time variability. Johnson et al. [79] support this hypothesis with a spectral analysis of reaction time variability revealing that absence of the 7-repeat allele is associated with drifting sustained attention resulting in inconsistent performance within a larger sample of Irish children with ADHD. Contrary to these findings, Langley and colleagues [93] report that carriers of the 7-repeat allele showed greater impulsiveness (faster reaction time) than non-carriers; Waldman et al. [179] referred to longer reaction times for homozygous carriers of the 7-repeat allele and Kieling et al. [82] described that presence of the 7-repeat allele was associated with more commission errors during a continuous performance task (CPT). Finally, Barkley and colleagues [12] reported no differences across a range of tests. However, in summary association of high reaction time variability with the 7-repeat allele absence appears to be the most consistent result and seems to be specific to ADHD [81]. The overall importance of these studies seeking to link genotype with neuropsychological functioning are limited by a range of methodological issues the most important of which are, relatively small sample sizes, a failure to account for the neuropsychological heterogeneity of ADHD, a lack of standardisation of neuropsychological tasks between studies and the use of clinically focused tasks rather than tasks that are based in neuroscience [33]. For a more detailed review of the relationship between candidate genes for ADHD and neuropsychological phenotypes see [81].

Regarding correlates between specific DRD4 genotypes and structural anatomical findings, Durston et al. [44] suggested that variations in $D R D 4$ influence prefrontal grey matter volume in a sample of subjects that included individuals with ADHD as well as their unaffected siblings, and healthy controls. Monuteaux et al. [125] also reported findings in adults with ADHD showing that 7-repeat allele carriers have a significantly smaller mean volume in the superior frontal cortex and cerebellum cortex when compared to subjects without this particular allele. Whilst Shaw et al. [156] found that carrying the DRD4 7-repeat allele was associated with having a thinner right orbitofrontal/ inferior prefrontal and posterior parietal cortex-regions overlapping those found to be thinner in ADHD - this same group were found to have better clinical outcomes. They also had a distinct trajectory of cortical development with a normalization of right parietal cortical thickening during adolescence. This has also previously been linked to having a better clinical outcome. However, two other studies reported that possession of the DRD4 7-repeat allele was associated with greater persistence of ADHD over time [92]. Based on the finding that 7-repeat allele carriers more likely exhibit antisocial behaviour, an alternative hypothesis has been proposed which suggests that possession of the DRD4 7-repeat allele influences the association between ADHD and conduct disorder [76].

The most frequently investigated gene $\times$ gene or marker $\times$ marker interaction in ADHD is the interaction of DRD4 (7-repeat allele) and DAT1 (10-repeat allele; see below). Based on results of two studies on Chilean families, Carrasco et al. [26] and Henriquez et al. [74] suggested that neither the DRD4 7-repeat nor the DAT1 10-repeat allele result in genotype frequency differences between affected children and their healthy siblings. However, the simultaneous presence of both, DRD4 7-repeat heterozygosity and DAT1 10-repeat allele homozygosity was more frequent in affected children as compared to their healthy siblings. Qian et al. [135] failed to replicate these initial findings. A fourth study which tried to confirm the interaction in a Mexican sample revealed no association with ADHD, neither for the individual markers nor for their combination [59]. Kebir et al. [81] analysed these markers and their relationship to IQ in a French sample. Besides their not detecting an association, they suggest that the verbal quotient as a specific domain of the IQ is correlated to the level of externalizing behaviour in boys with ADHD who carry the risk genotypes of both markers. In fact Mill et al. [122] were the first to suggest that DRD4 (and DAT1) exert their effects on ADHD by influencing IQ in a population-based sample, although it should be noted that Sonuga-Barke et al. [161] were unable to replicate these findings in the sample of the International Multi-centre ADHD Gene (IMAGE) project. In sum, the publications on gene $\times$ gene interactions are inconclusive and require further investigations in much larger samples or a meta-analysis to rule out false conclusions.

\section{Other dopamine receptors}

The $148 \mathrm{bp}$ allele of a dinucleotide $(\mathrm{CA})_{\mathrm{n}}$ repeat polymorphism located $18.5 \mathrm{~kb} 5^{\prime}$ of the dopamine D5 receptor gene (DRD5), has also received considerable attention. While two meta-analyses supported an association with ADHD (pooled odds ratio 1.3) [98, 112], Mill et al. [123] and Loo et al. [110] found no evidence for a relationship between DRD5 status and a range of cognitive endophenotypes of ADHD in samples of moderate size (for a more detailed discussion of the endophenotype approach see below). Recently, Langley et al. [92] reported an association of the $148 \mathrm{bp}$ allele with persistence of ADHD from childhood to adolescence in a longitudinal study.

Allelic variants of the dopamine D1, D2 and D3 receptors have also been investigated with conflicting results. A first study reported evidence for an association between variants of DRDI and ADHD. The receptor 
encoded by this gene is mainly located in the prefrontal cortex and in the striatum and it was suggested that it may modulate working memory capacity and may be associated specifically with inattention. The re-analysis of genotype data of a GWAS of the IMAGE sample revealed nominal significance of single nucleotide polymorphisms (SNPs) in DRD1 for association to ADHD [130] as well as an association to time-to-onset of ADHD [94]. Two polymorphisms in the non-translated $5^{\prime}$ region and one marker in the non-translated $3^{\prime}$ region were associated with an increased risk for ADHD (odds ratio 1.3, each) [124]. This particular finding, however, was not replicated in a candidate study in the IMAGE sample [21]. An association of DRD2 SNPs with CPT phenotypes in ADHD has been brought up by Kollins et al. [87]. Moreover, there is also some evidence for an involvement of the dopamine D3 receptor gene (DRD3) in the aetiology of ADHD: Guan et al. [65] reported a nominally significant association in a Chinese Han population, whereas the results of Davis et al. [37] indicate a role of the DRD3 in the manifestation of hyperactive/impulsive symptoms of ADHD. However, the findings concerning both $D R D 2[87,120,180]$ and $D R D 3$ $[21,37,120,180]$ are inconsistent and require further investigation in independent samples.

\section{Dopamine transporter gene (DAT1/SLC6A3)}

The dopamine transporter is expressed primarily in the striatum and the nucleus accumbens and is a site of action of methylphenidate. Consequently, the association between ADHD and variations in the DATI gene has been extensively studied. The $D A T 1$ gene contains a $40 \mathrm{bp}$ variable number tandem repeat (VNTR) polymorphism in the nontranslated $3^{\prime}$ region. The 9-repeat allele (440 bp) $(23.4 \%)$ and the 10-repeat allele (480 bp) $(71.9 \%)$ are the most frequent alleles [177] in Caucasian populations. The 10repeat allele is possibly related to an increased mesolimbic expression of the transporter [177].

Although there have been many reports supporting a positive association between DATI and ADHD, there are also negative findings. A recent meta-analysis found a significant heterogeneity between family-based European association studies (stronger effects) and Asian case-control studies (weaker effects), and did not support an overall significant association between DAT1 and ADHD [98]. Further evidence of possible ethnicity effects comes from studies that indicated associations in case-control studies in Afro-Caribbean subjects [10] which were not detected in Middle-Eastern subjects [10]. Similarly, a small Indian family study found evidence for association of ADHD and the shorter 9-repeat allele rather than the 10-repeat allele usually found to be associated with ADHD in other studies [36]. Another group has suggested that the 10-repeat allele of DATl is associated with increased risk for ADHD only in the presence of another functional variant. In two studies they found increased risk only if a combination of the 10repeat allele and a 6-repeat allele of a 30-bp VNTR in intron 8 of the DATl gene were both present $[6,23]$. Whereas Brüggemann and co-workers [25] did not find an association for this haplotype with the adult form of ADHD, Franke et al. [55] reported that the 9-6 haplotype rather than the 10-6 haplotype is more likely to be associated with childhood ADHD. This finding was recently replicated in a sample of 1,440 ADHD cases which persisted into adulthood and 1,769 controls from the International Multicentre persistent ADHD CollaboraTion (IMpACT) project [57]. In a Brazilian sample, Genro et al. $[61,62]$ found preferential transmission of a common haplotype in the $5^{\prime}$ region to offspring with ADHD whereas they found no association to any haplotype in the $3^{\prime}$ region of the gene. Recently, further evidence for the presence of at least two loci associated with ADHD within the DATI was described. While Friedel et al. [58] detected a haplotype spanning the first three introns of the gene with relative risks of 1.95 and 2.43 for heterozygous and homozygous carriers, respectively, Brookes et al. [24] replicated their initial association of SNPs at the $5^{\prime}$ end of the gene and identified a haplotype spanning the $5^{\prime}$ and $3^{\prime}$ markers. Underlining these observations, Xu et al. [193] report an association of genetic variation in the promoter region of DAT1 with ADHD in samples from both the UK and Taiwan. Zhou et al. [195] suggested that the presence or absence of conduct disorder might influence the association of DAT1 with ADHD. They analysed genotypes of 20 DAT1 markers in 576 trios, 141 of whom had comorbid conduct disorder and found that DATl was only associated with ADHD when conduct disorder was not present; interestingly two independent association signals were present in ADHD without CD (but not ADHD $+\mathrm{CD}$ ) at both, the $5^{\prime}$ and $3^{\prime}$ end of the DAT1 gene. In addition, three studies suggested that the genetic associations to ADHD and in particular those for DATl may depend on gender: While the effect sizes for the ADHD association observed by Biederman et al. [19] were stronger when stratified by sex, e.g. for DAT1 in males, Hawi et al. [72] reported paternal over-transmission of risk alleles for ADHD, especially for the VNTR in the $3^{\prime}$ non-translated region. A second study of the same group in 1,248 ADHD nuclear families also provided support for a parent of origin effect for the intron 8 and $3^{\prime}$ non-translated region VNTRs as well as the paternal risk haplotype of both [71]. Exploring parent of origin effects in the IMAGE sample, Anney et al. [2] found no evidence to support an overall parent of origin effect for 554 independent markers of 47 ADHD candidate genes, including markers in DAT1. Based on these contradictory findings further studies of the association of the 
DAT1 alleles and ADHD in large datasets that allow investigating the role of age-related changes, ethnicity and gender effects, gene-environmental interactions, parent of origin effects, and the influence of comorbidity patterns are needed.

Regarding structural anatomical correlates, Durston et al. [44] reported that DATI variability influences caudate, but not prefrontal cortex volume. A functional imaging study suggested that the DATl genotype affects activation in the striatum and cerebellar vermis and that the familial risk of ADHD is related to the striatum but not to the vermis which requires further support [45].

There is also evidence that variations in the DATl gene have a significant effect on aspects of executive neuropsychological functioning [80]. Significant genotype effects were found for performance on the "Tower of London" and on the "Wechsler Intelligence Scale for Children Freedom From Distractibility Index"; children with ADHD with the 9-repeat/10-repeat genotype exhibited poorer performance on these measures as compared to children with the 10-repeat/10-repeat genotype [80]. Contrary to these findings, Bellgrove et al. [14] found that ADHD patients with the 10-repeat/10-repeat genotype had a greater attentional bias in a CPT than those with the other allele combinations. Barkley et al. [12] again found effects of DATl status on neuropsychological functioning, but only in their control group where those with the 9-repeat/ 10-repeat genotype performed less well on a CPT. Also, Loo et al. [110] detected no relationship between DAT1 status and a range of cognitive performance measures in children with ADHD. A systematic review of studies investigating links between the VNTR in the $3^{\prime}$ untranslated region of the DATI and neurophysiological and neuropsychological measures concluded that the majority of studies did not find a relation between DATI and either of these measures [148]. An associated study of 350 children and adolescents with ADHD and 195 non-affected siblings using a broad set of executive/cognitive and motor tests concluded that whilst several of the DAT1 polymorphisms were associated with ADHD and whilst ADHD was associated with impaired neuropsychological functioning, none of the DAT1 polymorphisms was convincingly associated with neuropsychological dysfunctions [148]. As before the relevance of the studies investigating potential links between genotype and neuropsychological functioning are limited by design issues.

The DAT1 gene may also influence the response to medication. Thus, Loo et al. [111] reported that DAT1 alleles may mediate medication-related EEG changes in ADHD, with children with ADHD and two copies of the 10-repeat allele showing increased and 9-repeat carriers with ADHD showing decreased cortical activation and arousal after a single 10-mg dose of methylphenidate.
Other dopaminergic genes

No clear evidence has been reported to support an association between ADHD and variations in the tyrosine hydroxylase gene $(T H)$, which catalyzes the conversion of tyrosine to dopa. Ribases et al. [143] found the dopamine decarboxylase gene $(D D C)$-whose enzyme is responsible for catalyzing the conversion of dopa to dopamine and L5 hydroxytryptophan to serotonin-to be strongly associated with both adult and childhood ADHD. Two further studies support this finding: one analysis of the IMAGE data [95] as well as a study on a Chinese Han sample also found a nominally significant association [65]. There are, however, also negative results from an earlier analysis that included a subsample of patients from the IMAGE sample [21].

Several studies have reported an association between ADHD and a polymorphism (TaqI) of the dopamine beta hydroxylase gene $(D B H)$ that encodes for the enzyme that catalyzes the conversion of dopamine to noradrenaline (pooled odds ratio $\sim 1.3$ ). However, there were differences between studies with increased risk being associated with the A2 allele in some studies, but with the A1 allele in others $[120,180]$. Bellgrove et al. [15, 16] reported an association between the A2 allele of the TaqI $D B H$ polymorphism and impaired temporal resolution and sustained attention, with those homozygous for the A2 allele performing worse than those without this genotype. Barkley et al. [12] found the A2 allele to be associated with poor performance on a card playing task in adulthood and, when for individuals homozygous for A2, in adolescence. Kieling et al. [82] reported an association between a different polymorphism of $D B H$ - the $-1021 \mathrm{C}>\mathrm{T}$ polymorphism, which may account for up to $50 \%$ reduction of the enzymatic activity-and measures of executive functioning in 64 drug-naive patients with ADHD. Cognitive performance measured by a composite score was significantly different between genotype groups, with the CC homozygous carriers having a poorer global executive performance. In contrast, Hess et al. [75] detected no association between the $-1021 \mathrm{C}>\mathrm{T}$ polymorphism and ADHD, but suggested that the marker may be related to impulsive personality traits in an adult ADHD sample. Finally, the re-analysis of the IMAGE GWAS data revealed a nominally significant association finding at the $D B H$ locus and ADHD [95]; the same finding was also described in a Chinese Han population [65].

A recent meta-analysis of studies investigating the association between the Val/Met polymorphism of the catechol-o-methyltransferase (COMT) gene at codon 158 and ADHD concluded that the current evidence does not support an association with the disorder [29]. This conclusion is supported by results from the IMAGE project on 
this polymorphism [21]. Subsequent studies have reported both association [47, 94, 95], no association [160] or a more complicated mode of action. Halleland and coworkers identified a haplotype including the Val158Met polymorphism associated with adult ADHD [68]. A study by Sengupta et al. [155] showed that the Val/Met polymorphism modulates task-oriented behaviour, but it does not modulate the response of this behaviour to MPH treatment. Moreover, a study by Retz et al. [140] reported that a specific haplotype combination of COMT variants and variants of the noradrenaline transporter gene (NET/ SLC6A2, see below) may be related to low ADHD scores. Furthermore, a report by Thapar et al. [171] suggests that the Val158Met variation in the COMT gene previously associated with altered executive functioning is actually associated with antisocial behaviour in ADHD, rather than with ADHD itself. Caspi et al. [28] reported similar findings showing that homozygous valine carriers at codon 158 of the COMT gene were more aggressive than those with the other two genotypes. Consequently, other studies focused on the relationship between COMT genotypes and ADHD comorbid disorders, such as conduct disorder (CD) and oppositional defiant disorder (ODD). Monuteaux et al. [125] did not detect an association between SNPs in the COMT gene and the risk for $\mathrm{CD}$ in an ADHD sample, whereas Qian et al. [136] reported on an association of the Val/Met variant with ADHD and comorbid ODD in a Chinese sample.

A number of studies have reported on additional dopaminergic genes. A potential involvement of the MAOA gene in ADHD was reported [35, 65, 149, 189] even though these positive findings were inconsistent regarding the risk alleles [120, 180]. Moreover, others failed to find association [114, 136]. While it may still be possible that variations in the MAOA gene are associated with persistence of ADHD into adolescence [100] and play a role in the variation in neuropsychological performance [149], Thapar et al. [172] suggested that variation in MAOA is associated with antisocial behaviour in ADHD, but not with ADHD itself. Gender is a further factor that could mask effects of the gene on ADHD, Rommelse et al. [149], Das et al. [35] and recently Biederman et al. [19] reported gender differences in the association between gene variation and ADHD traits and suggested that the MAOA gene may explain some of the known gender differences in ADHD. As a possible mode of action, Rommelse et al. [149] described that an ATT haplotype of MAOA was associated with poor motor control in boys whereas it was associated with better visuo-spatial working memory in girls. Besides the MAOA gene, there are also reports on variants of the $M A O B$ gene that were described to be associated with adult ADHD in a Spanish sample [143] and two additional studies [101, 143].

\section{Noradrenergic system}

While stimulant medications appear to act primarily by regulating dopamine levels in the brain, noradrenergic and serotonergic functions may also be affected by ADHD medications [159]. In addition, adrenergic neurotransmitter systems are hypothesized to influence attentional processes and certain aspects of executive control [4]. The most frequently investigated genes of the noradrenergic system are those encoding the noradrenaline transporter (NET1/ $S L C 6 A 2)$ and the adrenergic alpha receptors $2 \mathrm{~A}$ and $2 \mathrm{C}$ (ADRA2A and ADRA2C). Additionally, there is some evidence for a potential involvement of the genes for alpha receptors-1A and $1 \mathrm{~B}$ (encoded by $A D R A 1 A$ and $A D R A 2 B$ ) and beta receptor 1 and 2 (ADRB1 and $A D R B 2)$ in the aetiology of ADHD [95].

An initial positive finding for the noradrenaline transporter (NET1/SLC6A2) [34] was followed by several studies that found no association [13, 30, 119]. Recently, several additional variants of the noradrenaline transporter have been associated to ADHD [20, 22, 65, 83, 84, 86, 95, 191, 192] and require further attention and more elaborate analyses. One example of such an analysis was already described above, suggesting that variations in the noradrenaline transporter may show effects in the presence of specific variants in the COMT gene (and vice versa), only [140]. Additionally, two studies also suggested genderspecific effects: Biederman et al. [19] found variants in NET1/SLC6A2 to be associated more strongly with ADHD in females, whereas Anney et al. [2] reported about paternal over transmission of risk alleles to affected individuals.

Regarding other candidate genes of the noradrenergic system, there is growing evidence for involvement of genetic variants of the adrenergic receptor alpha-2A gene $(A D R A 2 A)$ in ADHD [2, 30, 39, 145, 152, 184]. It may be that these variants are more relevant for inattentive than hyperactive/impulsive symptoms [145, 152]. Also it has been suggested that there is a relationship between $A D R A 2 A$ polymorphisms and neuropsychological functioning that may moderate but not mediate the association to ADHD [181].

Investigating another adrenergic receptor gene, Cho et al. [31] reported associations between variants of the alpha-2C adrenergic receptor gene (ADRA2C) and ADHD in their sample of Korean subjects. They found that homozygous carriers of the $\mathrm{C}$ allele of the Dral polymorphism in $A D R A 2 C$ showed a trend towards increased response time variability while individuals homozygous for the $\mathrm{G}$ allele at the $\mathrm{Mspl}$ polymorphism had a trend towards decreased response time variability. Guan et al. [65] reported suggestive significance for an association of $A D R A 2 C$ variants with ADHD combined type. 
Finally, the alpha-1A adrenergic receptor gene $(A D R A 1 A)$ and the beta-2 adrenergic receptor gene $(A D R B 2)$ were two of the genes with nominal significance in the study of Brookes et al. [21] that were also identified by Lasky-Su et al. [95]. Very recently, Elia et al. [47] also described a potential association between $A D R A 1 A$ and ADHD.

\section{Serotonergic system}

Serotonin dysregulation has been related to impulsive behaviour in children [69], and thus has been hypothesized to play a causal role in ADHD [129]. "Knockout" gene studies in mice, in which the behavioural effects of the deactivation of specific genes are examined, have further demonstrated the potential relevance of serotonergic genes [60]. The main candidate genes studied within the serotonergic system are those coding for the serotonin transporter (5-HTT/SLC6A4), the $1 \mathrm{~B}$ and $2 \mathrm{~A}$ serotonin receptors $(H T R 1 B)$ and $(H T R 2 A)$ and the dopamine decarboxylase $(D D C)$ and tryptophan hydroxylase $(T P H 2)$ genes. Several other serotonin receptor genes have also been studied much less extensively.

A meta-analysis has supported an association between ADHD and a 44-base-pair insertion/deletion (5-HTTLPR) in the promoter region of the serotonin transporter gene (5HTT/SLC6A4); this insertion/deletion causes long or short alleles with the long variant coding a functionally more active transporter which may contribute to the ADHD association (pooled odds ratio $\sim 1.3$ ) [53]. However, although there have been further replications since this meta-analysis [89, 104, 139] several studies have failed to replicate this finding [21, 64, 120, 187, 188] while still others have found the other allele to be associated $[1,104]$. Moreover, there have also been reports that the association of 5-HTTLPR may only be present when paired with an intron-2 (STin2) polymorphism [11] and that the intron-2 (STin2) polymorphism itself may be the variant more relevant for ADHD.

There are also contradictory findings for the potential association of the serotonin receptors with ADHD. A metaanalysis supported an association between the HTR $1 B$ gene and ADHD (pooled odds ratio 1.44; [53]), and although there are subsequent additional replications for HTR $1 B$ [70, 137], there are again also negative findings [21, 77]. Similarly, several groups have reported positive findings for HTR2A [67, 143], whilst others have failed to find an association [40, 146]. An analysis of the IMAGE study reported an association with the previously unstudied $H T R 1 E$ gene but did not find an association to HTR2C or $H T R 3 B$ [95]. Isolated findings in Chinese Han subjects and others have been reported for several other serotonin receptor genes including those coding for HTR $1 D$ [108, 109], HTR2C [106, 190] and HTR4 [102] but not others HTR5A and HTR6 [103]. Li et al. [99] also reported that polymorphisms of the HTR $2 A$ and HTR2C genes are related to functional remission in ADHD.

$\mathrm{Li}$ and colleagues have also reported on ADHD associations for the tryptophan hydroxylase 2 gene $(\mathrm{TPH} 2)$ which mediates the transformation of tryptophan to 5-hydroxytryptophan [105, 107]. These findings have been replicated in independent samples [21, 95, 157, 182]. Moreover, an analysis of the IMAGE data revealed nominal significance for an association between $T P H 2$ variants and overt aggressive impulsivity [130]. Baehne et al. [8] reported that $\mathrm{TPH} 2$ gene variants modulate response control processes in adult ADHD patients and healthy individuals. Regarding tryptophan hydroxylase 1 (TPHI), no ADHD association was found in the IMAGE sample [21]. Finally, Ribases et al. [143] reported that the $D D C$ gene, which mediates the transformation of 5-hydroxytryptophan to serotonin, is associated to both adult and childhood ADHD.

\section{Other candidate genes}

Additional candidate genes that have been studied include genes related to the following non-exhaustive list of gene products: Synaptosome-associated protein of $25,000 \mathrm{Da}$ (SNAP25), nicotinic acetylcholine receptor alpha 4 (CHRNA4), the glutamate (NMDA) receptor, brain derived neurotrophic factor $(B D N F)$, nerve growth factor $(N G F)$ and its receptor $(N G F R)$, neurotrophins 3 and 4/5 (NTF3 and $N T F 4 / 5)$, ciliary neurotrophic factor $(C N T F)$ and its receptor $(C N T F R)$, glial derived neurotrophic factor $(G D N F)$ and the receptors for neurotrophic tyrosine kinase, type 1-3 (NTRK1, NTRK2 and NTRK3), low affinity nerve growth factor receptor ( $L N G F R$ or p75 neurotrophin receptor), solute carrier family member 9A9 (SLC9A9), cannabinoid receptor $1(C N R 1 / C B 1)$ and nitric oxide synthase 1 (NOS1) [21, 95].

For SNAP25, meta-analyses of studies indicated significance of association findings for ADHD [52], for SLC9A9 also cytogenetic findings point to a role in ADHD [38], and for the functional Val66Met variant of $B D N F$, a very recent meta-analysis of the IMpACT project data showed no association with ADHD with or without comorbid mood disorders, in a large clinical sample of clinical adult ADHD cases $(n=1,445)$ and controls $(n=2,247)$ [151]. For the other genes mentioned above the results of the association analyses are either first reports based on samples of small or moderate size or where there is more than one report with contradictory findings. Obviously, contradictory results can arise for many reasons, but inadequate power to 
detect associations with small effect sizes and inexplicit analysis plans with multiple post hoc comparisons are the most common and obvious problems. To address this issue, carefully planned meta-analyses on studies with adequate quality or primary studies of sufficient size are needed.

\section{Genome-wide association studies in ADHD}

Genome-wide association studies have been a very successful tool for the recent identification of multiple risk genes for multifactorial (complex) disorders [116]. They combine the power to detect genetic variants of small effect size, like the association studies, with the possibility to perform hypothesis-free analyses of the entire genome. However, large sample sizes are needed in order to detect genetic risk factors with modest effects. So far, GWAS in ADHD have been published for two different samples, a subsample of the International Multicentre ADHD Genetics (IMAGE) study on childhood ADHD and a sample of adults with ADHD. These studies will be reviewed below. For a more detailed review see also [56].

The various GWAS analyses of the IMAGE sample that were published together in a special issue on ADHD genetics in the Am. J. Med. Genet. Part B (2008), used different approaches to identify risk genes. The IMAGE GWAS sample comprised a sample of 958 case-parent trio's with most of the cases diagnosed with combined subtype ADHD. The data were analysed using both quantitative [95] and categorical [127] phenotype definitions. The quantitative analysis revealed two significant findings: one for a genetic variant in the $\mathrm{CDH} 13$ gene associated with total ADHD symptom count, the other for a genetic variant in GFOD1, the gene coding for glucose-fructose oxidoreductase domain containing protein 1 , associated with inattentive symptoms. Another interesting finding from this study (though not statistically significant) included a variant in NOS1, which had previously been identified as a candidate gene for ADHD [138]. The categorical analysis did not reveal any genes or variants of genomewide significance, but $\mathrm{CDH} 13$ was also among the topfindings identified in this analysis, as was a variant in CNR1/CB1, a gene found associated with ADHD in earlier candidate gene based association studies [113, 133].

A whole genome gene-environment interaction study of parental expressed emotion (maternal warmth and criticism) looking at ADHD severity (and conduct problems) was also conducted using the same dataset, although there were again no genome-wide significant findings [162]. Additional GWAS in the IMAGE dataset so far included a study of time of onset of hyperactive/impulsive and inattentive symptoms [94] and one on conduct problems in ADHD [2].
The GWAS of adult ADHD patients used a pooled approach involving 343 adult ADHD patients and 304 controls [96]. The results of this study were compared to those of a linkage analysis carried out earlier by the same group [146] to prioritize the most interesting findings for further analysis. Although no genome-wide significant variants resulted from this study, the highest ranking findings also include the $\mathrm{CDH} 13$ gene. This gene emerges hitherto as one of the most consistent findings from the ADHD GWAS. In addition, it is supported by other sources, e.g. being located on chromosome 16q24 within the only significant linkage peak from a meta-analysis of seven linkage studies in ADHD [196]. Since $\mathrm{CDH} 13$ also showed association with different addiction-related phenotypes in GWAS (review by Uhl et al. [175]), was among the topfindings from a GWAS of the personality trait extraversion [170], showed strong association with schizophrenia in a genome-wide study [164], and may contain copy number variants $(\mathrm{CNV})$ related to autism [32], it seems to be a generalist gene, predisposing to multiple brain phenotypes [90]. $\mathrm{CDH} 13$ encodes cadherin 13, a protein expressed in neurons regulating cell migration and cell-cell communication [56].

Although only very few significant findings emerged from the individual ADHD GWAS, so far, and overlap between studies is still very limited, there are a few systems that seem to be overrepresented in the top-ranks of the different studies and a number of general themes seem to be emerging from the data. The most striking one is the possible involvement of genes related to cell adhesion and cell migration in ADHD aetiology, such as genes from cadherin, catenin and integrin families (Table 1), with $\mathrm{CDH} 13$ as the top-finding.

A second system showing up in these studies is that of potassium-related signalling (Table 2). This type of signalling is involved in regulating synaptic excitability and neuronal plasticity [85]. An interesting finding from the GWAS is that whilst signals relating to cell-cell communication genes related to glutamate, vasopressin and TAFA mediated signalling are observed the classical catecholaminergic and serotonergic neurotransmission ADHD candidate genes are absent from the high-ranking findings. However, since the power of these studies is still rather limited, the involvement of the genes for the classical neurotransmission systems in ADHD aetiology is not precluded.

Notably, nearly all of the genes listed in the top-ranks of the published ADHD GWAS belong to the largest genes within the human genome (Franke, unpublished observation), which may also point to insufficient power of the studies to detect association with smaller genes. As indicated above, some of the genes from candidate gene studies do show up in the GWAS, most notably CNRI and NOS1. 


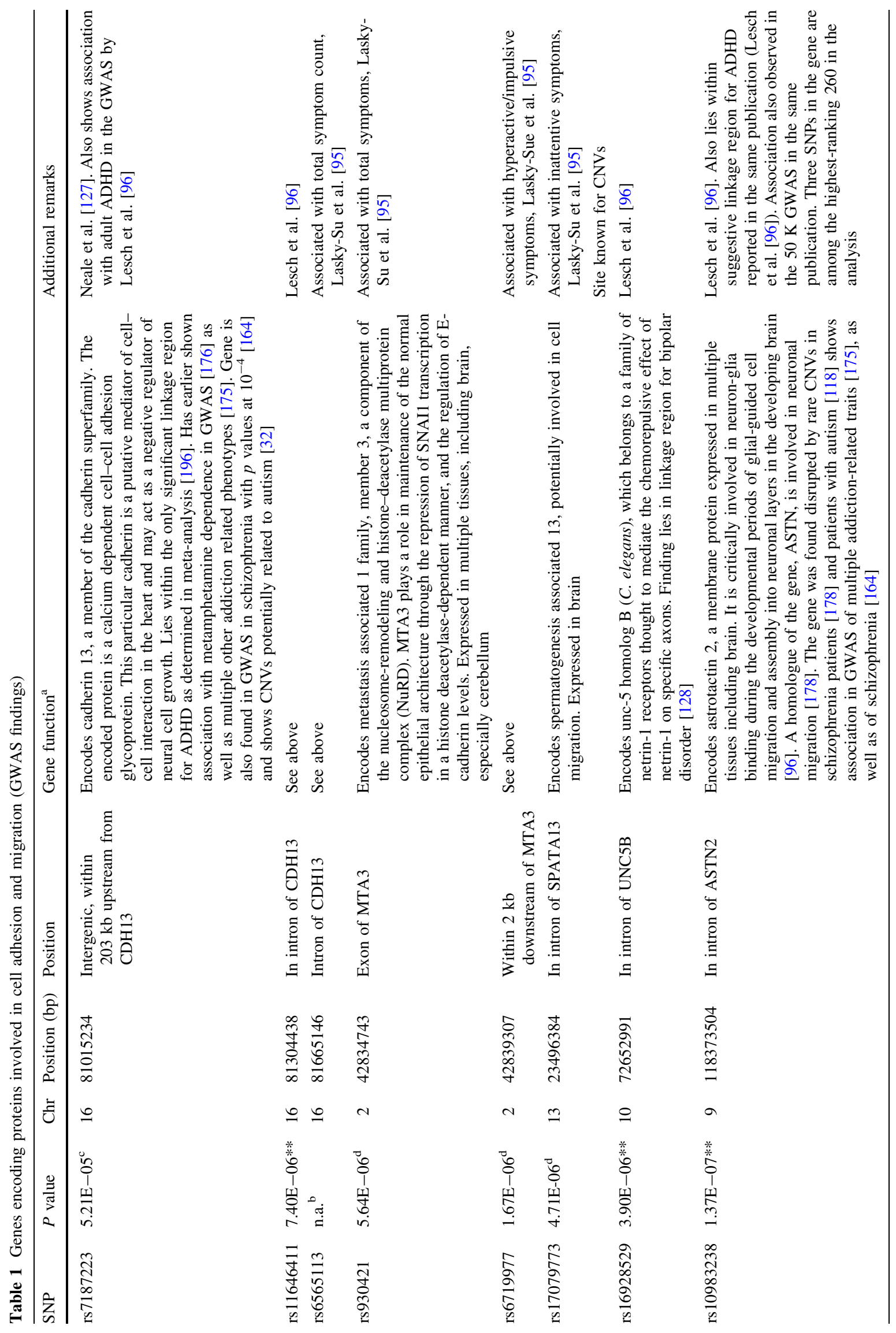




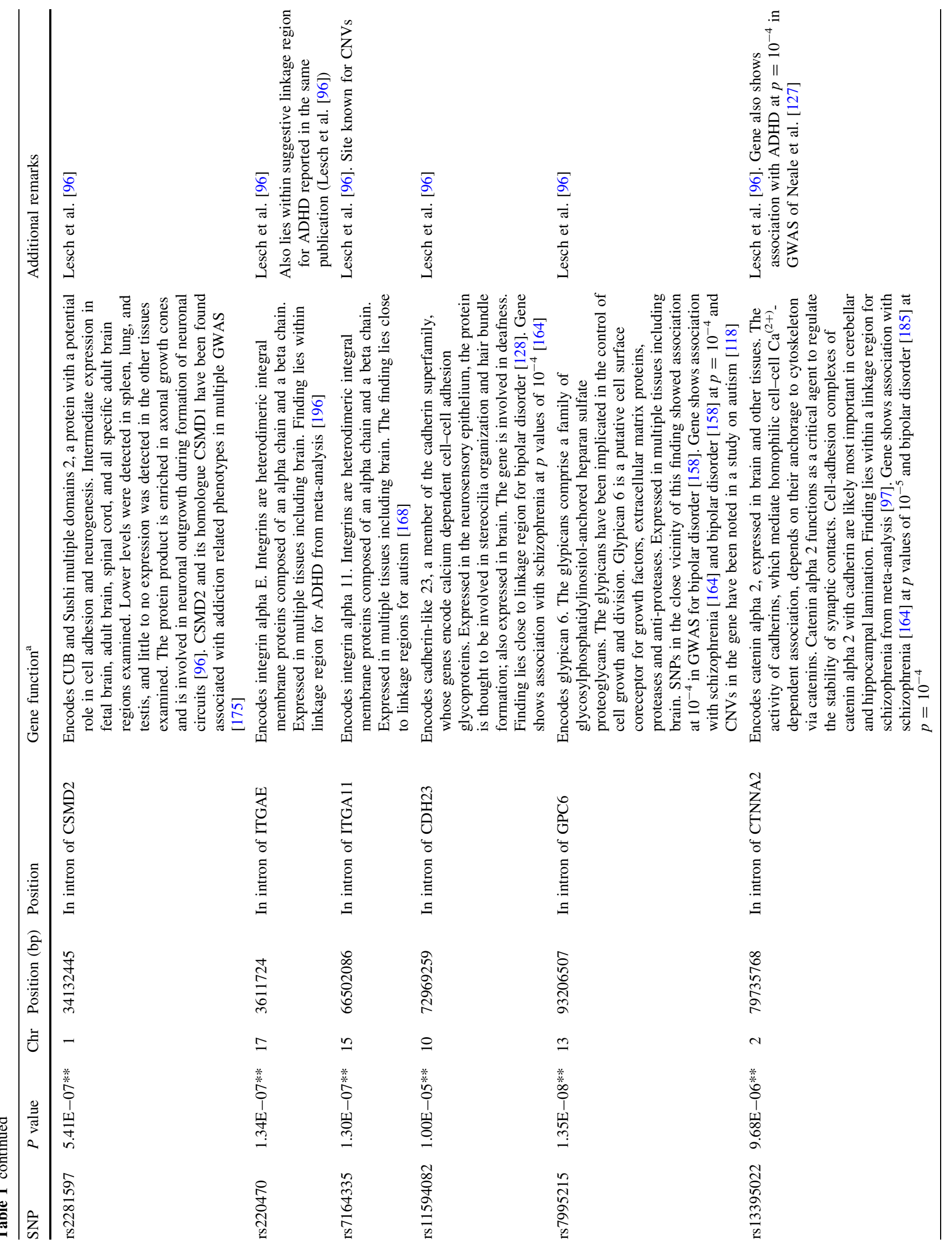




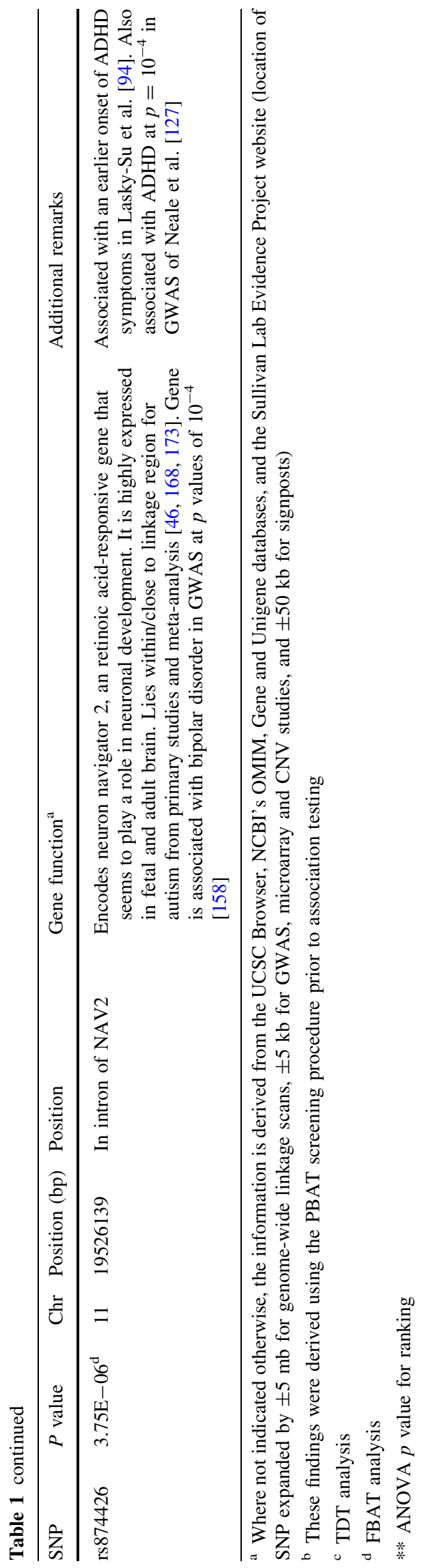

Also more basic cell processes related to cell division, gene transcription, cell polarity and extracellular matrix regulation, as well as cytoskeletal remodeling could be involved in ADHD [95, 96, 127]; see [56] for a review.

Whilst the current GWAS published for ADHD are far from providing a full understanding of the processes contributing to ADHD, they do provide us with new directions and suggest avenues follow. Comparing the findings to those from GWAS and linkage studies in other psychiatric disorders suggests extensive overlap between disorders. If this is due to overlap at the level of diagnostics or to genetic overlap between disorders remains to be explored.

\section{Future directions in ADHD genetics research}

To date, the findings from genetic studies in ADHD have been somewhat inconsistent and disappointing. Despite the high heritability of the disorder, linkage studies have not shown extensive overlaps, with only one significant finding in the meta-analysis of studies [196]. Candidate gene based association studies have similarly only explained a small percentage of the genetic component of ADHD and the first GWAS did not report many significant findings. Nevertheless, the latter approach is likely to redirect future ADHD research given the apparent involvement of new gene systems and processes, as summarized above.

Comparing GWAS in psychiatric disorders in general with those in other multifactorial diseases one finds that the performance of GWAS in psychiatric disorders has been particularly poor, explaining less than $10 \%$ of the observed variance for most of the disorders, so far [115]. The failure of the GWAS to identify the genes involved in psychiatric disorders with high heritability may have a number of causes: (1) multiple genetic factors may be involved that may have very small individual effects and might only be identified through studies with extremely large sample sizes; (2) gene-gene $(G \times G)$ and geneenvironment $(\mathrm{G} \times \mathrm{E})$ interactions may be making a strong contribution to the observed heritability of psychiatric disorders; (3) genetic factors other than the single nucleotide polymorphisms (SNPs) investigated in most studies may play important roles; thus, CNVs, i.e., structural variations in DNA, such as insertions, deletions and duplications, which are frequently occurring but widely varying in the population, might be involved in ADHD aetiology; (4) the role of rare genetic variants with large effect sizes in disease aetiology may be greater than anticipated; (5) the currently available nosological systems used for the clinical diagnosis of psychiatric disorders may be clinically valid but may not be strongly related to the biological underpinnings of such disorders, or may not be specific enough to pick up genes; and (6) it 


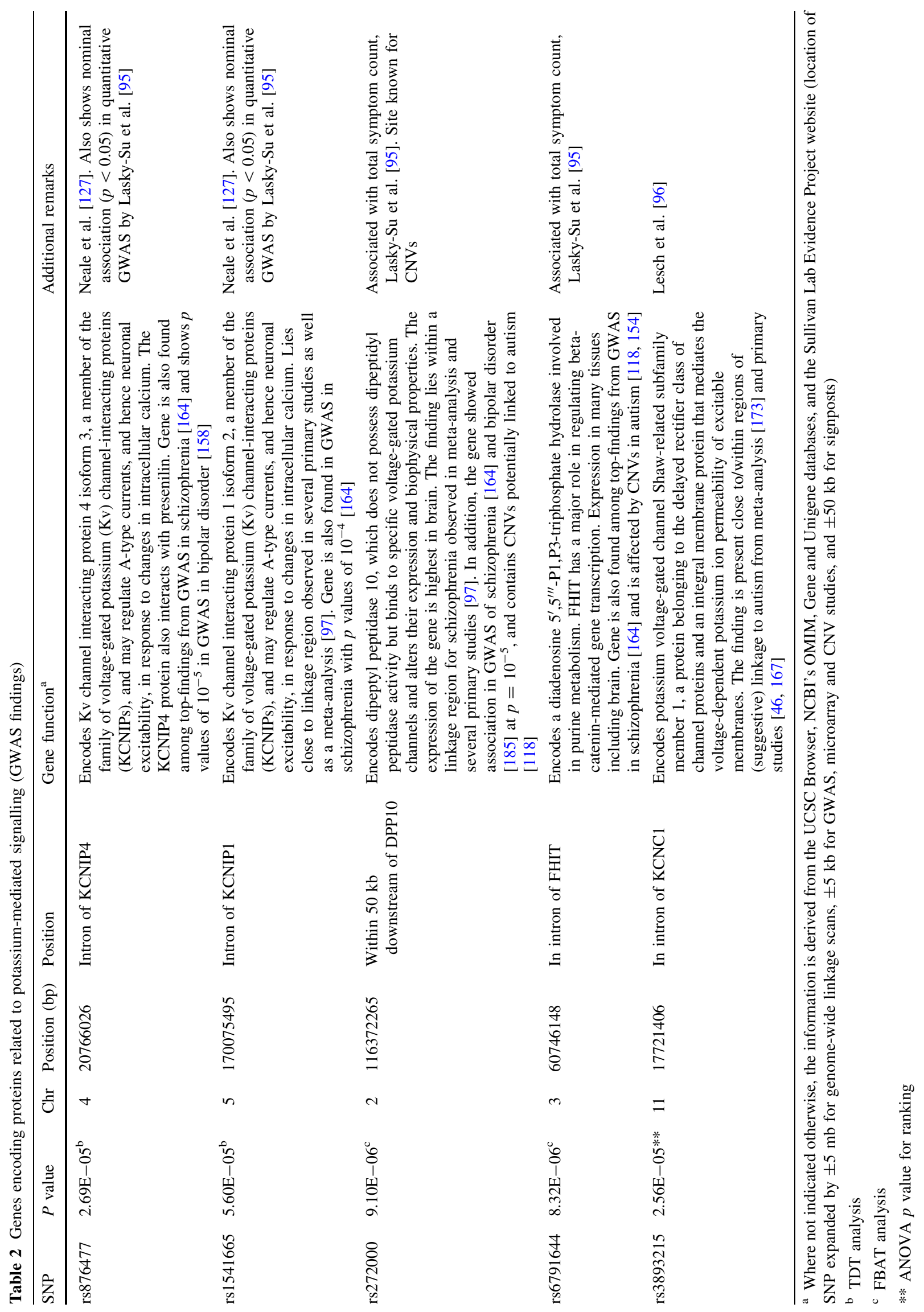


must be kept in mind, that the samples studied differ in age (persistent vs. non-persistent ADHD), method of recruitment and ascertainment, ethnicity, gender and comorbidity and that each of these factors might have an impact. These issues need to be dealt with, before we can fully understand the genetic architecture of ADHD. The issue of sample size is currently tackled by establishing large international collaborations, such as the ADHD Molecular Genetics Network [49] and the Psychiatric GWAS Consortium [134], and large (meta-analytic) studies of GWAS in ADHD can be expected within the next year. The $G \times G$ and $G \times E$ effects are not yet taken into account in most current studies, but some potentially important $\mathrm{G} \times \mathrm{G}$ and $\mathrm{G} \times \mathrm{E}$ interactions have been demonstrated. It is likely that new statistical approaches will need to be developed, before we can sufficiently handle these effects with confidence. Until now, most studies have focussed on SNPs only, however, this type of polymorphism is not informative for all genetic factors present in the human genome, and we might need to use other techniques, such as next generation sequencing [153] to get more information on these other genetic factors. This approach may also solve the problem with rare variants. Point (5), the potential limitations through the use of the current diagnostic system for genetic studies, can potentially be addressed by using more refined phenotypes. Refinement of the ADHD phenotype may be possible by concentrating on the most heritable subtypes of ADHD. This has already been implemented in the IMAGE study, which concentrated on combined subtype ADHD [91]. Recently, the IMpACT project was set up by research groups from The Netherlands, Germany, Spain, Norway, the UK and the US to perform and promote genetic research in the persistent, adult form of ADHD [57]. Although the heritability of this form of the disorder has not formally been established, it seems that it may be higher than that of the childhood disorder [48]. To date, IMpACT coordinates the largest clinical sample of adult ADHD, with more than 2,700 cases and 3,500 controls. A more radical adaptation in phenotypes for genetic studies in ADHD is the use of endophenotypes. Endophenotypes, or intermediate phenotypes, are thought to represent heritable phenotypic constructs that are more directly related to genes than clinical symptoms or disease categories [63, 169, 183]. The success of an endophenotype strategy requires either a higher heritability of the endophenotype as compared to the disease phenotype (which is not generally observed, [167]) or a reduced complexity of the genetic architecture of the endophenotype due to the involvement of fewer genes. ADHD endophenotypes have been identified at different levels, based on neuropsychological performance [41, 147] and on neuroimaging
[43] i.e. brain activity and structure. Such studies seem to work well, the first examples of linkage studies show significant findings in samples of relatively limited size (e.g. $[42,150])$ and so do (candidate gene based) association findings (e.g. references to Durston et al. [45]). Especially the latter seem to produce more highly powered studies due to larger effect sizes of individual genetic variants $[121,126]$. The penetrance of genetic variants may be especially high for functional neuroimaging [121]). However, it needs to be taken into account that initial studies of genetic associations frequently tend to over-estimate true effect sizes [174]; thus, we need to be cautious about interpretation of the initial studies of endophenotypes in relatively small sample sizes.

Endophenotype approaches come at the cost of reduced specificity for ADHD, so not all genes explaining variance of an endophenotype will also increase ADHD risk in the end; however, it is not yet clear whether factors such as course or treatment response are more closely related to ADHD per se or to a particular endophenotype.

Furthermore, endophenotype studies will also help to characterize the neural systems affected by risk gene variants and to elucidate quantitative, mechanistic aspects of brain function implicated in ADHD, and thus improve our understanding of the functional role of genes in ADHD and the specific pathways from gene to behaviour.

In conclusion, genetic studies have started to unravel the molecular architecture of ADHD, and several new exciting directions have recently been suggested. Future success in identifying more ADHD genes will critically depend on collaboration between researchers and an improvement of approaches at the level of the phenotype definition, the molecular genetic techniques, as well as statistical analysis methods. Even if the ADHD risk genes have such small effect sizes in the population, their identification may still be highly relevant clinically, because low frequency gene variants may actually explain most of the heritability in individual patients and because a subsequent understanding of their functions and the pathways between each gene and behaviour may finally translate into an improvement of diagnostic processes and treatment strategies as well as a development of prediction and prevention programs with substantial impact [132].

Acknowledgments This work was supported by a grant from the German Research Foundation (Deutsche Forschungsgemeinschaft, DFG: HE 1446/9-1).

Open Access This article is distributed under the terms of the Creative Commons Attribution Noncommercial License which permits any noncommercial use, distribution, and reproduction in any medium, provided the original author(s) and source are credited.

Disclosures of potential conflicts of interests Dr. Banaschewski served in an advisory or consultancy role for Desitin, Lilly, Medice, 
Novartis, Pfizer, Shire, UCB. He received conference attendance support and conference support or received speaker's fee by Lilly, Janssen McNeil, Medice, Novartis, Shire, UCB and Viforpharma. He is/has been involved in clinical trials conducted by Lilly, Shire and Novartis. The present work is unrelated to the above grants and relationships.

Dr Becker is/has been involved in research/clinical trials with Eli Lilly and Shire, is on the advisory board of Eli Lilly/Germany, was paid for public speaking by Eli Lilly and received conference attendance support from Shire and Eli Lilly. The present work is unrelated to the above grants and relationships.

Dr. Coghill received research support from Eli Lilly and Shire, speakers fee from Eli Lilly, Janssen-Cilag, Shire, UCB, Flynn Pharma, and Medice, and served in an advisory board or consultancy role for Eli Lilly, Janssen-Cilag, Shire, UCB, Flynn Pharma, Pfizer, Schering-Plough. The present work is unrelated to the above grants and relationships.

Dr. Franke has no potential conflict of interest.

Dr. Scherag has no potential conflict of interest.

\section{References}

1. Adams J, Crosbie J, Wigg K, Ickowicz A, Pathare T, Roberts W, Malone M, Schachar R, Tannock R, Kennedy JL, Barr CL (2004) Glutamate receptor, ionotropic, $N$-methyl D-aspartate $2 \mathrm{~A}$ (GRIN2A) gene as a positional candidate for attention-deficit/ hyperactivity disorder in the $16 \mathrm{p} 13$ region. Mol Psychiatry 9:494-499

2. Anney RJ, Hawi Z, Sheehan K, Mulligan A, Pinto C, Brookes KJ, $\mathrm{Xu}$ X, Zhou K, Franke B, Buitelaar J, Vermeulen SH, Banaschewski T, Sonuga-Barke E, Ebstein R, Manor I, Miranda A, Mulas F, Oades RD, Roeyers H, Rommelse N, Rothenberger A, Sergeant J, Steinhausen HC, Taylor E, Thompson M, Asherson P, Faraone SV, Gill M (2008) Parent of origin effects in attention/ deficit hyperactivity disorder (ADHD): analysis of data from the international multicenter ADHD genetics (IMAGE) program. Am J Med Genet B Neuropsychiatr Genet 147B:1495-1500

3. Arcos-Burgos M, Castellanos FX, Pineda D, Lopera F, Palacio JD, Palacio LG, Rapoport JL, Berg K, Bailey-Wilson JE, Muenke M (2004) Attention-deficit/hyperactivity disorder in a population isolate: linkage to loci at 4q13.2, 5q33.3, 11q22, and 17p11. Am J Hum Genet 75:998-1014

4. Arnsten AF (2006) Fundamentals of attention-deficit/hyperactivity disorder: circuits and pathways. J Clin Psychiatry 67(Suppl 8):7-12

5. Asghari V, Sanyal S, Buchwaldt S, Paterson A, Jovanovic V, Van Tol HH (1995) Modulation of intracellular cyclic AMP levels by different human dopamine D4 receptor variants. J Neurochem 65:1157-1165

6. Asherson P, Brookes K, Franke B, Chen W, Gill M, Ebstein RP, Buitelaar J, Banaschewski T, Sonuga-Barke E, Eisenberg J, Manor I, Miranda A, Oades RD, Roeyers H, Rothenberger A, Sergeant J, Steinhausen HC, Faraone SV (2007) Confirmation that a specific haplotype of the dopamine transporter gene is associated with combined-type ADHD. Am J Psychiatry 164:674-677

7. Asherson P, Zhou K, Anney RJ, Franke B, Buitelaar J, Ebstein R, Gill M, Altink M, Arnold R, Boer F, Brookes K, Buschgens C, Butler L, Cambell D, Chen W, Christiansen H, Feldman L, Fleischman K, Fliers E, Howe-Forbes R, Goldfarb A, Heise A, Gabriels I, Johansson L, Lubetzki I, Marco R, Medad S, Minderaa R, Mulas F, Muller U, Mulligan A, Neale B, Rijsdijk F, Rabin K, Rommelse N, Sethna V, Sorohan J, Uebel H, Psychogiou L,
Weeks A, Barrett R, Xu X, Banaschewski T, Sonuga-Barke E, Eisenberg J, Manor I, Miranda A, Oades RD, Roeyers H, Rothenberger A, Sergeant J, Steinhausen HC, Taylor E, Thompson M, Faraone SV (2008) A high-density SNP linkage scan with 142 combined subtype ADHD sib pairs identifies linkage regions on chromosomes 9 and 16. Mol Psychiatry 13:514-521

8. Baehne CG, Ehlis AC, Plichta MM, Conzelmann A, Pauli P, Jacob C, Gutknecht L, Lesch KP, Fallgatter AJ (2009) Tph2 gene variants modulate response control processes in adult ADHD patients and healthy individuals. Mol Psychiatry 14:1032-1039

9. Bakker SC, van der Meulen EM, Buitelaar JK, Sandkuijl LA, Pauls DL, Monsuur AJ, van 't Slot R, Minderaa RB, Gunning WB, Pearson PL, Sinke RJ (2003) A whole-genome scan in 164 Dutch sib pairs with attention-deficit/hyperactivity disorder: suggestive evidence for linkage on chromosomes $7 \mathrm{p}$ and $15 \mathrm{q}$. Am J Hum Genet 72:1251-1260

10. Ballon N, Leroy S, Roy C, Bourdel MC, Olie JP, Charles-Nicolas A, Krebs MO, Poirier MF (2007) Polymorphisms TaqI A of the DRD2, BalI of the DRD3, exon III repeat of the DRD4, and 3' UTR VNTR of the DAT: association with childhood ADHD in male African-Caribbean cocaine dependents? Am J Med Genet B Neuropsychiatr Genet 144B:1034-1041

11. Banerjee E, Sinha S, Chatterjee A, Gangopadhyay PK, Singh M, Nandagopal K (2006) A family-based study of Indian subjects from Kolkata reveals allelic association of the serotonin transporter intron-2 (STin2) polymorphism and attention-deficithyperactivity disorder (ADHD). Am J Med Genet B Neuropsychiatr Genet 141B:361-366

12. Barkley RA, Smith KM, Fischer M, Navia B (2006) An examination of the behavioral and neuropsychological correlates of three ADHD candidate gene polymorphisms (DRD4 7+, DBH TaqI A2, and DAT1 40 bp VNTR) in hyperactive and normal children followed to adulthood. Am J Med Genet B Neuropsychiatr Genet 141B:487-498

13. Barr CL, Kroft J, Feng Y, Wigg K, Roberts W, Malone M, Ickowicz A, Schachar R, Tannock R, Kennedy JL (2002) The norepinephrine transporter gene and attention-deficit hyperactivity disorder. Am J Med Genet 114:255-259

14. Bellgrove MA, Barry E, Johnson KA, Cox M, Daibhis A, Daly M, Hawi Z, Lambert D, Fitzgerald M, McNicholas F, Robertson IH, Gill M, Kirley A (2008) Spatial attentional bias as a marker of genetic risk, symptom severity, and stimulant response in ADHD. Neuropsychopharmacology 33:2536-2545

15. Bellgrove MA, Hawi Z, Gill M, Robertson IH (2006) The cognitive genetics of attention deficit hyperactivity disorder (ADHD): sustained attention as a candidate phenotype. Cortex 42:838-845

16. Bellgrove MA, Hawi Z, Lowe N, Kirley A, Robertson IH, Gill M (2005) DRD4 gene variants and sustained attention in attention deficit hyperactivity disorder (ADHD): effects of associated alleles at the VNTR and -521 SNP. Am J Med Genet B Neuropsychiatr Genet 136B:81-86

17. Bhaduri N, Das M, Sinha S, Chattopadhyay A, Gangopadhyay PK, Chaudhuri K, Singh M, Mukhopadhyay K (2006) Association of dopamine D4 receptor (DRD4) polymorphisms with attention deficit hyperactivity disorder in Indian population. Am J Med Genet B Neuropsychiatr Genet 141B:61-66

18. Biederman J, Faraone SV (2005) Attention-deficit hyperactivity disorder. Lancet 366:237-248

19. Biederman J, Kim JW, Doyle AE, Mick E, Fagerness J, Smoller JW, Faraone SV (2008) Sexually dimorphic effects of four genes (COMT, SLC6A2, MAOA, SLC6A4) in genetic associations of ADHD: a preliminary study. Am J Med Genet B Neuropsychiatr Genet 147B:1511-1518

20. Bobb AJ, Addington AM, Sidransky E, Gornick MC, Lerch JP, Greenstein DK, Clasen LS, Sharp WS, Inoff-Germain G, 
Wavrant-De Vrieze F, Arcos-Burgos M, Straub RE, Hardy JA, Castellanos FX, Rapoport JL (2005) Support for association between ADHD and two candidate genes: NET1 and DRD1. Am J Med Genet B Neuropsychiatr Genet 134B:67-72

21. Brookes K, Xu X, Chen W, Zhou K, Neale B, Lowe N, Anney R, Franke B, Gill M, Ebstein R, Buitelaar J, Sham P, Campbell D, Knight J, Andreou P, Altink M, Arnold R, Boer F, Buschgens C, Butler L, Christiansen H, Feldman L, Fleischman K, Fliers E, Howe-Forbes R, Goldfarb A, Heise A, Gabriels I, Korn-Lubetzki I, Johansson L, Marco R, Medad S, Minderaa R, Mulas F, Muller U, Mulligan A, Rabin K, Rommelse N, Sethna V, Sorohan J, Uebel H, Psychogiou L, Weeks A, Barrett R, Craig I, Banaschewski T, Sonuga-Barke E, Eisenberg J, Kuntsi J, Manor I, McGuffin P, Miranda A, Oades RD, Plomin R, Roeyers H, Rothenberger A, Sergeant J, Steinhausen HC, Taylor E, Thompson M, Faraone SV, Asherson P (2006) The analysis of 51 genes in DSM-IV combined type attention deficit hyperactivity disorder: association signals in DRD4, DAT1 and 16 other genes. Mol Psychiatry 11:934-953

22. Brookes KJ, Knight J, Xu X, Asherson P (2005) DNA pooling analysis of $\mathrm{ADHD}$ and genes regulating vesicle release of neurotransmitters. Am J Med Genet B Neuropsychiatr Genet 139B:33-37

23. Brookes KJ, Mill J, Guindalini C, Curran S, Xu X, Knight J, Chen CK, Huang YS, Sethna V, Taylor E, Chen W, Breen G, Asherson P (2006) A common haplotype of the dopamine transporter gene associated with attention-deficit/hyperactivity disorder and interacting with maternal use of alcohol during pregnancy. Arch Gen Psychiatry 63:74-81

24. Brookes KJ, Xu X, Anney R, Franke B, Zhou K, Chen W, Banaschewski T, Buitelaar J, Ebstein R, Eisenberg J, Gill M, Miranda A, Oades RD, Roeyers H, Rothenberger A, Sergeant J, Sonuga-Barke E, Steinhausen HC, Taylor E, Faraone SV, Asherson P (2008) Association of ADHD with genetic variants in the 5'-region of the dopamine transporter gene: evidence for allelic heterogeneity. Am J Med Genet B Neuropsychiatr Genet 147B:1519-1523

25. Brüggemann D, Sobanski E, Alm B, Schubert T, Schmalzried H, Philipsen A, Breen G, Becker T, Georgi A, Skowronek MH, Schulze TG, Treutlein J, Rietschel M (2007) No association between a common haplotype of the 6 and 10-repeat alleles in intron 8 and the 3'UTR of the DAT1 gene and adult attention deficit hyperactivity disorder. Psychiatr Genet 17:121

26. Carrasco X, Rothhammer P, Moraga M, Henriquez H, Chakraborty R, Aboitiz F, Rothhammer F (2006) Genotypic interaction between DRD4 and DAT1 loci is a high risk factor for attention-deficit/hyperactivity disorder in Chilean families. Am J Med Genet B Neuropsychiatr Genet 141B:51-54

27. Casey BJ, Nigg JT, Durston S (2007) New potential leads in the biology and treatment of attention deficit-hyperactivity disorder. Curr Opin Neurol 20:119-124

28. Caspi A, Langley K, Milne B, Moffitt TE, O'Donovan M, Owen MJ, Polo Tomas M, Poulton R, Rutter M, Taylor A, Williams B, Thapar A (2008) A replicated molecular genetic basis for subtyping antisocial behavior in children with attention-deficit/ hyperactivity disorder. Arch Gen Psychiatry 65:203-210

29. Cheuk DK, Wong V (2006) Meta-analysis of association between a catechol-O-methyltransferase gene polymorphism and attention deficit hyperactivity disorder. Behav Genet 36:651-659

30. Cho SC, Kim JW, Kim BN, Hwang JW, Park M, Kim SA, Cho DY, Yoo HJ, Chung US, Son JW, Park TW (2008) No evidence of an association between norepinephrine transporter gene polymorphisms and attention deficit hyperactivity disorder: a family-based and case-control association study in a Korean sample. Neuropsychobiology 57:131-138
31. Cho SC, Kim JW, Kim BN, Hwang JW, Shin MS, Park M, Kim SA, Cho DY, Yoo HJ, Chung US, Son JW, Park TW (2008) Association between the alpha-2C-adrenergic receptor gene and attention deficit hyperactivity disorder in a Korean sample. Neurosci Lett 446:108-111

32. Christian SL, Brune CW, Sudi J, Kumar RA, Liu S, Karamohamed S, Badner JA, Matsui S, Conroy J, McQuaid D, Gergel J, Hatchwell E, Gilliam TC, Gershon ES, Nowak NJ, Dobyns WB, Cook EH Jr (2008) Novel submicroscopic chromosomal abnormalities detected in autism spectrum disorder. Biol Psychiatry 63:1111-1117

33. Coghill D, Banaschewski T (2009) The genetics of attentiondeficit/hyperactivity disorder. Expert Rev Neurother 9:15471565

34. Comings DE, Gade-Andavolu R, Gonzalez N, Wu S, Muhleman D, Blake H, Dietz G, Saucier G, MacMurray JP (2000) Comparison of the role of dopamine, serotonin, and noradrenaline genes in ADHD, ODD and conduct disorder: multivariate regression analysis of 20 genes. Clin Genet 57:178-196

35. Das M, Bhowmik AD, Sinha S, Chattopadhyay A, Chaudhuri K, Singh M, Mukhopadhyay K (2006) MAOA promoter polymorphism and attention deficit hyperactivity disorder (ADHD) in Indian children. Am J Med Genet B Neuropsychiatr Genet 141B:637-642

36. Das M, Mukhopadhyay K (2007) DAT1 3'-UTR 9R allele: preferential transmission in Indian children with attention deficit hyperactivity disorder. Am J Med Genet B Neuropsychiatr Genet 144B:826-829

37. Davis C, Patte K, Levitan RD, Carter J, Kaplan AS, Zai C, Reid C, Curtis C, Kennedy JL (2009) A psycho-genetic study of associations between the symptoms of binge eating disorder and those of attention deficit (hyperactivity) disorder. J Psychiatr Res 43:687-696

38. de Silva MG, Elliott K, Dahl HH, Fitzpatrick E, Wilcox S, Delatycki M, Williamson R, Efron D, Lynch M, Forrest S (2003) Disruption of a novel member of a sodium/hydrogen exchanger family and DOCK3 is associated with an attention deficit hyperactivity disorder-like phenotype. J Med Genet 40:733-740

39. Deupree JD, Smith SD, Kratochvil CJ, Bohac D, Ellis CR, Polaha J, Bylund DB (2006) Possible involvement of alpha-2A adrenergic receptors in attention deficit hyperactivity disorder: radioligand binding and polymorphism studies. Am $\mathrm{J}$ Med Genet B Neuropsychiatr Genet 141B:877-884

40. Dorval KM, Wigg KG, Crosbie J, Tannock R, Kennedy JL, Ickowicz A, Pathare T, Malone M, Schachar R, Barr CL (2007) Association of the glutamate receptor subunit gene GRIN2B with attention-deficit/hyperactivity disorder. Genes Brain Behav 6:444-452

41. Doyle AE, Faraone SV, Seidman LJ, Willcutt EG, Nigg JT, Waldman ID, Pennington BF, Peart J, Biederman J (2005) Are endophenotypes based on measures of executive functions useful for molecular genetic studies of ADHD? J Child Psychol Psychiatry 46:774-803

42. Doyle AE, Ferreira MA, Sklar PB, Lasky-Su J, Petty C, Fusillo SJ, Seidman LJ, Willcutt EG, Smoller JW, Purcell S, Biederman J, Faraone SV (2008) Multivariate genomewide linkage scan of neurocognitive traits and ADHD symptoms: suggestive linkage to 3q13. Am J Med Genet B Neuropsychiatr Genet 147B:1399-1411

43. Durston S, de Zeeuw P, Staal WG (2009) Imaging genetics in ADHD: a focus on cognitive control. Neurosci Biobehav Rev 33:674-689

44. Durston S, Fossella JA, Casey BJ, Hulshoff Pol HE, Galvan A, Schnack HG, Steenhuis MP, Minderaa RB, Buitelaar JK, Kahn RS, van Engeland H (2005) Differential effects of DRD4 and DAT1 genotype on fronto-striatal gray matter volumes in a sample of subjects with attention deficit hyperactivity disorder, their unaffected siblings, and controls. Mol Psychiatry 10:678-685 
45. Durston S, Fossella JA, Mulder MJ, Casey BJ, Ziermans TB, Vessaz MN, Van Engeland H (2008) Dopamine transporter genotype conveys familial risk of attention-deficit/hyperactivity disorder through striatal activation. J Am Acad Child Adolesc Psychiatry 47:61-67

46. Duvall JA, Lu A, Cantor RM, Todd RD, Constantino JN, Geschwind DH (2007) A quantitative trait locus analysis of social responsiveness in multiplex autism families. Am J Psychiatry 164:656-662

47. Elia J, Capasso M, Zaheer Z, Lantieri F, Ambrosini P, Berrettini W, Devoto M, Hakonarson H (2009) Candidate gene analysis in an on-going genome-wide association study of attention-deficit hyperactivity disorder: suggestive association signals in ADRA1A. Psychiatr Genet 19:134-141

48. Faraone SV (2004) Genetics of adult attention-deficit/hyperactivity disorder. Psychiatr Clin North Am 27:303-321

49. Faraone SV (2003) Report from the 4th international meeting of the attention deficit hyperactivity disorder molecular genetics network. Am J Med Genet B Neuropsychiatr Genet 121B:55-59

50. Faraone SV, Doyle AE, Lasky-Su J, Sklar PB, D'Angelo E, Gonzalez-Heydrich J, Kratochvil C, Mick E, Klein K, Rezac AJ, Biederman J (2008) Linkage analysis of attention deficit hyperactivity disorder. Am J Med Genet B Neuropsychiatr Genet 147B:1387-1391

51. Faraone SV, Doyle AE, Mick E, Biederman J (2001) Metaanalysis of the association between the 7-repeat allele of the dopamine $\mathrm{D}(4)$ receptor gene and attention deficit hyperactivity disorder. Am J Psychiatry 158:1052-1057

52. Faraone SV, Khan SA (2006) Candidate gene studies of attention-deficit/hyperactivity disorder. J Clin Psychiatry 67(Suppl 8):13-20

53. Faraone SV, Perlis RH, Doyle AE, Smoller JW, Goralnick JJ, Holmgren MA, Sklar P (2005) Molecular genetics of attentiondeficit/hyperactivity disorder. Biol Psychiatry 57:1313-1323

54. Fisher SE, Francks C, McCracken JT, McGough JJ, Marlow AJ, MacPhie IL, Newbury DF, Crawford LR, Palmer CG, Woodward JA, Del'Homme M, Cantwell DP, Nelson SF, Monaco AP, Smalley SL (2002) A genomewide scan for loci involved in attention-deficit/hyperactivity disorder. Am J Hum Genet 70:1183-1196

55. Franke B, Hoogman M, Arias Vasquez A, Heister JG, Savelkoul PJ, Naber M, Scheffer H, Kiemeney LA, Kan CC, Kooij JJ, Buitelaar JK (2008) Association of the dopamine transporter (SLC6A3/DAT1) gene 9-6 haplotype with adult ADHD. Am J Med Genet B Neuropsychiatr Genet 147B:1576-1579

56. Franke B, Neale BM, Faraone SV (2009) Genome-wide association studies in ADHD. Hum Genet 126:13-50

57. Franke B, Vasquez AA, Johansson S, Hoogman M, Romanos J, Boreatti-Hummer A, Heine M, Jacob CP, Lesch KP, Casas M, Ribases M, Bosch R, Sanchez-Mora C, Gomez-Barros N, Fernandez-Castillo N, Bayes M, Halmoy A, Halleland H, Landaas ET, Fasmer OB, Knappskog PM, Heister AJ, Kiemeney LA, Kooij JJ, Boonstra AM, Kan CC, Asherson P, Faraone SV, Buitelaar JK, Haavik J, Cormand B, RamosQuiroga JA, Reif A (2009) Multicenter analysis of the SLC6A3/DAT1 VNTR haplotype in persistent ADHD suggests differential involvement of the gene in childhood and persistent ADHD. Neuropsychopharmacology

58. Friedel S, Saar K, Sauer S, Dempfle A, Walitza S, Renner T, Romanos M, Freitag C, Seitz C, Palmason H, Scherag A, Windemuth-Kieselbach C, Schimmelmann BG, Wewetzer C, Meyer J, Warnke A, Lesch KP, Reinhardt R, Herpertz-Dahlmann B, Linder M, Hinney A, Remschmidt H, Schafer H, Konrad K, Hubner N, Hebebrand J (2007) Association and linkage of allelic variants of the dopamine transporter gene in ADHD. Mol Psychiatry 12:923-933
59. Gabriela ML, John DG, Magdalena BV, Ariadna GS, de Francisco LP, Liz SM, Lino PC, Josefina RG, Ernesto RZ, Carlos CF (2009) Genetic interaction analysis for DRD4 and DAT1 genes in a group of Mexican ADHD patients. Neurosci Lett 451: $257-260$

60. Gainetdinov RR, Wetsel WC, Jones SR, Levin ED, Jaber M, Caron MG (1999) Role of serotonin in the paradoxical calming effect of psychostimulants on hyperactivity. Science 283: 397-401

61. Genro JP, Polanczyk GV, Zeni C, Oliveira AS, Roman T, Rohde LA, Hutz MH (2008) A common haplotype at the dopamine transporter gene $5^{\prime}$ region is associated with attention-deficit/ hyperactivity disorder. Am J Med Genet B Neuropsychiatr Genet 147B:1568-1575

62. Genro JP, Zeni C, Polanczyk GV, Roman T, Rohde LA, Hutz $\mathrm{MH}$ (2007) A promoter polymorphism $(-839 \mathrm{C}>\mathrm{T})$ at the dopamine transporter gene is associated with attention deficit/ hyperactivity disorder in Brazilian children. Am J Med Genet B Neuropsychiatr Genet 144B:215-219

63. Gottesman II, Gould TD (2003) The endophenotype concept in psychiatry: etymology and strategic intentions. Am J Psychiatry 160:636-645

64. Grevet EH, Marques FZ, Salgado CA, Fischer AG, Kalil KL, Victor MM, Garcia CR, Sousa NO, Belmonte-de-Abreu P, Bau $\mathrm{CH}$ (2007) Serotonin transporter gene polymorphism and the phenotypic heterogeneity of adult ADHD. J Neural Transm 114:1631-1636

65. Guan L, Wang B, Chen Y, Yang L, Li J, Qian Q, Wang Z, Faraone SV, Wang Y (2009) A high-density single-nucleotide polymorphism screen of 23 candidate genes in attention deficit hyperactivity disorder: suggesting multiple susceptibility genes among Chinese Han population. Mol Psychiatry 14:546-554

66. Guan LL, Wang YF, Li J, Wang B, Yang L, Qian QJ (2007) Association analysis of dopamine D4 receptor gene polymorphism and attention deficit hyperactivity disorder with/without disruptive behavior disorder. Beijing Da Xue Xue Bao 39:233-236

67. Guimaraes AP, Zeni C, Polanczyk GV, Genro JP, Roman T, Rohde LA, Hutz MH (2007) Serotonin genes and attention deficit/hyperactivity disorder in a Brazilian sample: preferential transmission of the HTR2A 452His allele to affected boys. Am J Med Genet B Neuropsychiatr Genet 144B:69-73

68. Halleland H, Lundervold AJ, Halmoy A, Haavik J, Johansson S (2009) Association between catechol O-methyltransferase (COMT) haplotypes and severity of hyperactivity symptoms in adults. Am J Med Genet B Neuropsychiatr Genet 150B:403-410

69. Halperin JM, Newcorn JH, Schwartz ST, Sharma V, Siever LJ, Koda VH, Gabriel S (1997) Age-related changes in the association between serotonergic function and aggression in boys with ADHD. Biol Psychiatry 41:682-689

70. Hawi Z, Dring M, Kirley A, Foley D, Kent L, Craddock N, Asherson P, Curran S, Gould A, Richards S, Lawson D, Pay H, Turic D, Langley K, Owen M, O'Donovan M, Thapar A, Fitzgerald M, Gill M (2002) Serotonergic system and attention deficit hyperactivity disorder (ADHD): a potential susceptibility locus at the 5-HT(1B) receptor gene in 273 nuclear families from a multi-centre sample. Mol Psychiatry 7:718-725

71. Hawi Z, Kent L, Hill M, Anney RJ, Brookes KJ, Barry E, Franke B, Banaschewski T, Buitelaar J, Ebstein R, Miranda A, Oades RD, Roeyers H, Rothenberger A, Sergeant J, Sonuga-Barke E, Steinhausen HC, Faraone SV, Asherson P, Gill M (2009) ADHD and DAT1: further evidence of paternal over-transmission of risk alleles and haplotype. Am J Med Genet B Neuropsychiatr Genet

72. Hawi Z, Segurado R, Conroy J, Sheehan K, Lowe N, Kirley A, Shields D, Fitzgerald M, Gallagher L, Gill M (2005) Preferential transmission of paternal alleles at risk genes in attention-deficit/ hyperactivity disorder. Am J Hum Genet 77:958-965 
73. Hebebrand J, Dempfle A, Saar K, Thiele H, Herpertz-Dahlmann B, Linder M, Kiefl H, Remschmidt H, Hemminger U, Warnke A, Knolker U, Heiser P, Friedel S, Hinney A, Schafer H, Nurnberg P, Konrad K (2006) A genome-wide scan for attention-deficit/hyperactivity disorder in 155 German sib-pairs. Mol Psychiatry 11:196-205

74. Henriquez BH, Henriquez HM, Carrasco X, Rothhammer P, Llop RE, Aboitiz F, Rothhammer F (2008) Combinacion de genotipos DRD4 y DAT1 constituye importante factor de riesgo en miembros de familias de Santiago de Chile con deficit atencional. Rev Med Chil 136:719-724

75. Hess C, Reif A, Strobel A, Boreatti-Hummer A, Heine M, Lesch KP, Jacob CP (2009) A functional dopamine-beta-hydroxylase gene promoter polymorphism is associated with impulsive personality styles, but not with affective disorders. J Neural Transm 116:121-130

76. Holmes J, Payton A, Barrett J, Harrington R, McGuffin P, Owen M, Ollier W, Worthington J, Gill M, Kirley A, Hawi Z, Fitzgerald M, Asherson P, Curran S, Mill J, Gould A, Taylor E, Kent L, Craddock N, Thapar A (2002) Association of DRD4 in children with ADHD and comorbid conduct problems. Am J Med Genet 114:150-153

77. Ickowicz A, Feng Y, Wigg K, Quist J, Pathare T, Roberts W, Malone M, Schachar R, Tannock R, Kennedy JL, Barr CL (2007) The serotonin receptor HTR1B: gene polymorphisms in attention deficit hyperactivity disorder. Am J Med Genet B Neuropsychiatr Genet 144B:121-125

78. Ioannidis JP, Ntzani EE, Trikalinos TA, Contopoulos-Ioannidis DG (2001) Replication validity of genetic association studies. Nat Genet 29:306-309

79. Johnson KA, Kelly SP, Robertson IH, Barry E, Mulligan A, Daly M, Lambert D, McDonnell C, Connor TJ, Hawi Z, Gill M, Bellgrove MA (2008) Absence of the 7-repeat variant of the DRD4 VNTR is associated with drifting sustained attention in children with ADHD but not in controls. Am J Med Genet B Neuropsychiatr Genet

80. Karama S, Grizenko N, Sonuga-Barke E, Doyle A, Biederman J, Mbekou V, Polotskaia A, Ter-Stepanian M, De Guzman R, Bellingham J, Sengupta S, Joober R (2008) Dopamine transporter $3^{\prime}$ UTR VNTR genotype is a marker of performance on executive function tasks in children with ADHD. BMC Psychiatry $8: 45$

81. Kebir O, Grizenko N, Sengupta S, Joober R (2009) Verbal but not performance IQ is highly correlated to externalizing behavior in boys with ADHD carrying both DRD4 and DAT1 risk genotypes. Prog Neuropsychopharmacol Biol Psychiatry 33:939-944

82. Kieling C, Genro JP, Hutz MH, Rohde LA (2008) The -1021 C/ $\mathrm{T}$ DBH polymorphism is associated with neuropsychological performance among children and adolescents with ADHD. Am J Med Genet B Neuropsychiatr Genet 147B:485-490

83. Kim CH, Hahn MK, Joung Y, Anderson SL, Steele AH, MazeiRobinson MS, Gizer I, Teicher MH, Cohen BM, Robertson D, Waldman ID, Blakely RD, Kim KS (2006) A polymorphism in the norepinephrine transporter gene alters promoter activity and is associated with attention-deficit hyperactivity disorder. Proc Natl Acad Sci USA 103:19164-19169

84. Kim CH, Waldman ID, Blakely RD, Kim KS (2008) Functional gene variation in the human norepinephrine transporter: association with attention deficit hyperactivity disorder. Ann N Y Acad Sci 1129:256-260

85. Kim J, Hoffman DA (2008) Potassium channels: newly found players in synaptic plasticity. Neuroscientist 14:276-286

86. Kim JW, Biederman J, McGrath CL, Doyle AE, Mick E, Fagerness J, Purcell S, Smoller JW, Sklar P, Faraone SV (2008) Further evidence of association between two NET single- nucleotide polymorphisms with ADHD. Mol Psychiatry 13:624630

87. Kollins SH, Anastopoulos AD, Lachiewicz AM, FitzGerald D, Morrissey-Kane E, Garrett ME, Keatts SL, Ashley-Koch AE (2008) SNPs in dopamine D2 receptor gene (DRD2) and norepinephrine transporter gene (NET) are associated with continuous performance task (CPT) phenotypes in ADHD children and their families. Am J Med Genet B Neuropsychiatr Genet 147B:1580-1588

88. Konrad K, Dempfle A, Friedel S, Heiser P, Holtkamp K, Walitza S, Sauer S, Warnke A, Remschmidt H, Gilsbach S, Schafer H, Hinney A, Hebebrand J, Herpertz-Dahlmann B (2009) Familiality and molecular genetics of attention networks in ADHD. Am J Med Genet B Neuropsychiatr Genet

89. Kopeckova M, Paclt I, Petrasek J, Pacltova D, Malikova M, Zagatova V (2008) Some ADHD polymorphisms (in genes DAT1, DRD2, DRD3, DBH, 5-HTT) in case-control study of 100 subjects 6-10 age. Neuro Endocrinol Lett 29:246-251

90. Kovas Y, Plomin R (2006) Generalist genes: implications for the cognitive sciences. Trends Cogn Sci 10:198-203

91. Kuntsi J, Neale BM, Chen W, Faraone SV, Asherson P (2006) The IMAGE project: methodological issues for the molecular genetic analysis of ADHD. Behav Brain Funct 2:27

92. Langley K, Fowler TA, Grady DL, Moyzis RK, Holmans PA, van den Bree MB, Owen MJ, O'Donovan MC, Thapar A (2009) Molecular genetic contribution to the developmental course of attention-deficit hyperactivity disorder. Eur Child Adolesc Psychiatry 18:26-32

93. Langley K, Marshall L, van den Bree M, Thomas H, Owen M, O'Donovan M, Thapar A (2004) Association of the dopamine D4 receptor gene 7-repeat allele with neuropsychological test performance of children with ADHD. Am J Psychiatry 161:133138

94. Lasky-Su J, Anney RJ, Neale BM, Franke B, Zhou K, Maller JB, Vasquez AA, Chen W, Asherson P, Buitelaar J, Banaschewski T, Ebstein R, Gill M, Miranda A, Mulas F, Oades RD, Roeyers H, Rothenberger A, Sergeant J, Sonuga-Barke E, Steinhausen HC, Taylor E, Daly M, Laird N, Lange C, Faraone SV (2008) Genome-wide association scan of the time to onset of attention deficit hyperactivity disorder. Am J Med Genet B Neuropsychiatr Genet 147B:1355-1358

95. Lasky-Su J, Neale BM, Franke B, Anney RJ, Zhou K, Maller JB, Vasquez AA, Chen W, Asherson P, Buitelaar J, Banaschewski T, Ebstein R, Gill M, Miranda A, Mulas F, Oades RD, Roeyers H, Rothenberger A, Sergeant J, Sonuga-Barke E, Steinhausen HC, Taylor E, Daly M, Laird N, Lange C, Faraone SV (2008) Genome-wide association scan of quantitative traits for attention deficit hyperactivity disorder identifies novel associations and confirms candidate gene associations. Am J Med Genet B Neuropsychiatr Genet 147B:1345-1354

96. Lesch KP, Timmesfeld N, Renner TJ, Halperin R, Roser C, Nguyen TT, Craig DW, Romanos J, Heine M, Meyer J, Freitag C, Warnke A, Romanos M, Schafer H, Walitza S, Reif A, Stephan DA, Jacob C (2008) Molecular genetics of adult ADHD: converging evidence from genome-wide association and extended pedigree linkage studies. J Neural Transm 115:1573-1585

97. Lewis CM, Levinson DF, Wise LH, DeLisi LE, Straub RE, Hovatta I, Williams NM, Schwab SG, Pulver AE, Faraone SV, Brzustowicz LM, Kaufmann CA, Garver DL, Gurling HM, Lindholm E, Coon H, Moises HW, Byerley W, Shaw SH, Mesen A, Sherrington R, O'Neill FA, Walsh D, Kendler KS, Ekelund J, Paunio T, Lonnqvist J, Peltonen L, O'Donovan MC, Owen MJ, Wildenauer DB, Maier W, Nestadt G, Blouin JL, Antonarakis SE, Mowry BJ, Silverman JM, Crowe RR, Cloninger CR, Tsuang MT, Malaspina D, Harkavy-Friedman JM, Svrakic DM, Bassett AS, Holcomb J, Kalsi G, McQuillin A, 
Brynjolfson J, Sigmundsson T, Petursson H, Jazin E, Zoega T, Helgason T (2003) Genome scan meta-analysis of schizophrenia and bipolar disorder, part II: Schizophrenia. Am J Hum Genet 73:34-48

98. Li D, Sham PC, Owen MJ, He L (2006) Meta-analysis shows significant association between dopamine system genes and attention deficit hyperactivity disorder (ADHD). Hum Mol Genet 15:2276-2284

99. Li J, Kang C, Wang Y, Zhou R, Wang B, Guan L, Yang L, Faraone SV (2006) Contribution of 5-HT2A receptor gene $1438 \mathrm{~A}>\mathrm{G}$ polymorphism to outcome of attention-deficit/ hyperactivity disorder in adolescents. Am J Med Genet B Neuropsychiatr Genet 141B:473-476

100. Li J, Kang C, Zhang H, Wang Y, Zhou R, Wang B, Guan L, Yang L, Faraone SV (2007) Monoamine oxidase A gene polymorphism predicts adolescent outcome of attention-deficit/ hyperactivity disorder. Am J Med Genet B Neuropsychiatr Genet 144B:430-433

101. Li J, Wang Y, Hu S, Zhou R, Yu X, Wang B, Guan L, Yang L, Zhang F, Faraone SV (2008) The monoamine oxidase B gene exhibits significant association to ADHD. Am J Med Genet B Neuropsychiatr Genet 147:370-374

102. Li J, Wang Y, Zhou R, Wang B, Zhang H, Yang L, Faraone SV (2006) Association of attention-deficit/hyperactivity disorder with serotonin 4 receptor gene polymorphisms in Han Chinese subjects. Neurosci Lett 401:6-9

103. Li J, Wang Y, Zhou R, Wang B, Zhang H, Yang L, Faraone SV (2006) No association of attention-deficit/hyperactivity disorder with genes of the serotonergic pathway in Han Chinese subjects. Neurosci Lett 403:172-175

104. Li J, Wang Y, Zhou R, Zhang H, Yang L, Wang B, Faraone SV (2007) Association between polymorphisms in serotonin transporter gene and attention deficit hyperactivity disorder in Chinese Han subjects. Am J Med Genet B Neuropsychiatr Genet 144B:14-19

105. Li J, Wang Y, Zhou R, Zhang H, Yang L, Wang B, Faraone SV (2006) Association between tryptophan hydroxylase gene polymorphisms and attention deficit hyperactivity disorder in Chinese Han population. Am J Med Genet B Neuropsychiatr Genet 141B:126-129

106. Li J, Wang YF, Zhou RL, Yang L, Zhang HB, Wang B (2007) Association between serotonin 2C gene polymorphisms and attention deficit hyperactivity disorder in children with or without comorbidity of disruptive behavior disorder. Zhonghua Er Ke Za Zhi 45:374-377

107. Li J, Wang YF, Zhou RL, Yang L, Zhang HB, Wang B (2003) Association between tryptophan hydroxylase gene polymorphisms and attention deficit hyperactivity disorder with or without learning disorder. Zhonghua Yi Xue Za Zhi 83:2114-2118

108. Li J, Wang YF, Zhou RL, Zhang HB, Wang B, Yang L (2006) Association between serotonin 1D gene polymorphisms and attention deficit hyperactivity disorder comorbid or not comorbid disruptive behavior disorder. Beijing Da Xue Xue Bao 38:492-495

109. Li J, Zhang X, Wang Y, Zhou R, Zhang H, Yang L, Wang B, Faraone SV (2006) The serotonin 5-HT1D receptor gene and attention-deficit hyperactivity disorder in Chinese Han subjects. Am J Med Genet B Neuropsychiatr Genet 141B:874-876

110. Loo SK, Rich EC, Ishii J, McGough J, McCracken J, Nelson S, Smalley SL (2008) Cognitive functioning in affected sibling pairs with ADHD: familial clustering and dopamine genes. J Child Psychol Psychiatry 49:950-957

111. Loo SK, Specter E, Smolen A, Hopfer C, Teale PD, Reite ML (2003) Functional effects of the DAT1 polymorphism on EEG measures in ADHD. J Am Acad Child Adolesc Psychiatry 42:986-993
112. Lowe N, Kirley A, Hawi Z, Sham P, Wickham H, Kratochvil CJ, Smith SD, Lee SY, Levy F, Kent L, Middle F, Rohde LA, Roman T, Tahir E, Yazgan Y, Asherson P, Mill J, Thapar A, Payton A, Todd RD, Stephens T, Ebstein RP, Manor I, Barr CL, Wigg KG, Sinke RJ, Buitelaar JK, Smalley SL, Nelson SF, Biederman J, Faraone SV, Gill M (2004) Joint analysis of the DRD5 marker concludes association with attention-deficit/ hyperactivity disorder confined to the predominantly inattentive and combined subtypes. Am J Hum Genet 74:348-356

113. Lu AT, Ogdie MN, Jarvelin MR, Moilanen IK, Loo SK, McCracken JT, McGough JJ, Yang MH, Peltonen L, Nelson SF, Cantor RM, Smalley SL (2008) Association of the cannabinoid receptor gene (CNR1) with ADHD and post-traumatic stress disorder. Am J Med Genet B Neuropsychiatr Genet

114. Lung FW, Yang P, Cheng TS, Kao WT (2006) No allele variation of the MAOA gene promoter in male Chinese subjects with attention deficit hyperactivity disorder. Neuropsychobiology $54: 147-151$

115. Maher B (2008) Personal genomes: the case of the missing heritability. Nature 456:18-21

116. Manolio TA, Rodriguez LL, Brooks L, Abecasis G, Ballinger D, Daly M, Donnelly P, Faraone SV, Frazer K, Gabriel S, Gejman P, Guttmacher A, Harris EL, Insel T, Kelsoe JR, Lander E, McCowin N, Mailman MD, Nabel E, Ostell J, Pugh E, Sherry S, Sullivan PF, Thompson JF, Warram J, Wholley D, Milos PM, Collins FS (2007) New models of collaboration in genome-wide association studies: the Genetic Association Information Network. Nat Genet 39:1045-1051

117. Manor I, Tyano S, Eisenberg J, Bachner-Melman R, Kotler M, Ebstein RP (2002) The short DRD4 repeats confer risk to attention deficit hyperactivity disorder in a family-based design and impair performance on a continuous performance test (TOVA). Mol Psychiatry 7:790-794

118. Marshall CR, Noor A, Vincent JB, Lionel AC, Feuk L, Skaug J, Shago M, Moessner R, Pinto D, Ren Y, Thiruvahindrapduram B, Fiebig A, Schreiber S, Friedman J, Ketelaars CE, Vos YJ, Ficicioglu C, Kirkpatrick S, Nicolson R, Sloman L, Summers A, Gibbons CA, Teebi A, Chitayat D, Weksberg R, Thompson A, Vardy C, Crosbie V, Luscombe S, Baatjes R, Zwaigenbaum L, Roberts W, Fernandez B, Szatmari P, Scherer SW (2008) Structural variation of chromosomes in autism spectrum disorder. Am J Hum Genet 82:477-488

119. McEvoy B, Hawi Z, Fitzgerald M, Gill M (2002) No evidence of linkage or association between the norepinephrine transporter (NET) gene polymorphisms and ADHD in the Irish population. Am J Med Genet 114:665-666

120. Mick E, Faraone SV (2008) Genetics of attention deficit hyperactivity disorder. Child Adolesc Psychiatr Clin N Am 17:261-284 Vii-Viii

121. Mier D, Kirsch P, Meyer-Lindenberg A (2009) Neural substrates of pleiotropic action of genetic variation in COMT: a metaanalysis. Mol Psychiatry

122. Mill J, Caspi A, Williams BS, Craig I, Taylor A, Polo-Tomas M, Berridge CW, Poulton R, Moffitt TE (2006) Prediction of heterogeneity in intelligence and adult prognosis by genetic polymorphisms in the dopamine system among children with attention-deficit/hyperactivity disorder: evidence from 2 birth cohorts. Arch Gen Psychiatry 63:462-469

123. Mill J, Xu X, Ronald A, Curran S, Price T, Knight J, Craig I, Sham P, Plomin R, Asherson P (2005) Quantitative trait locus analysis of candidate gene alleles associated with attention deficit hyperactivity disorder (ADHD) in five genes: DRD4, DAT1, DRD5, SNAP-25, and 5HT1B. Am J Med Genet B Neuropsychiatr Genet 133B:68-73

124. Misener VL, Luca P, Azeke O, Crosbie J, Waldman I, Tannock R, Roberts W, Malone M, Schachar R, Ickowicz A, Kennedy JL, 
Barr CL (2004) Linkage of the dopamine receptor D1 gene to attention-deficit/hyperactivity disorder. Mol Psychiatry 9:500-509

125. Monuteaux MC, Biederman J, Doyle AE, Mick E, Faraone SV (2009) Genetic risk for conduct disorder symptom subtypes in an ADHD sample: specificity to aggressive symptoms. J Am Acad Child Adolesc Psychiatry 48:757-764

126. Munafo MR, Brown SM, Hariri AR (2008) Serotonin transporter (5-HTTLPR) genotype and amygdala activation: a meta-analysis. Biol Psychiatry 63:852-857

127. Neale BM, Lasky-Su J, Anney R, Franke B, Zhou K, Maller JB, Vasquez AA, Asherson P, Chen W, Banaschewski T, Buitelaar J, Ebstein R, Gill M, Miranda A, Oades RD, Roeyers H, Rothenberger A, Sergeant J, Steinhausen HC, Sonuga-Barke E, Mulas F, Taylor E, Laird N, Lange C, Daly M, Faraone SV (2008) Genome-wide association scan of attention deficit hyperactivity disorder. Am J Med Genet B Neuropsychiatr Genet 147B:1337-1344

128. Nurnberger JI, DePaulo JR, Gershon ES, Reich T, Blehar MC, Edenberg HJ, Foroud T, Miller M, Bowman E, Mayeda A, Rau NL, Smiley C, Conneally PM, McMahon F, Meyers D, Simpson S, McInnis M, Stine OC, Detera-Wadleigh S, Goldin L, Guroff J, Maxwell E, Kazuba D, Gejman PV, Badner J, Sanders A, Rice J, Bierut L, Goate A (1997) Genomic survey of bipolar illness in the NIMH genetics initiative pedigrees: a preliminary report. Am J Med Genet 74:227-237

129. Oades RD (2008) Dopamine-serotonin interactions in attentiondeficit hyperactivity disorder (ADHD). Prog Brain Res 172: 543-565

130. Oades RD, Lasky-Su J, Christiansen H, Faraone SV, SonugaBarke EJ, Banaschewski T, Chen W, Anney RJ, Buitelaar JK, Ebstein RP, Franke B, Gill M, Miranda A, Roeyers H, Rothenberger A, Sergeant JA, Steinhausen HC, Taylor EA, Thompson M, Asherson P (2008) The influence of serotoninand other genes on impulsive behavioral aggression and cognitive impulsivity in children with attention-deficit/hyperactivity disorder (ADHD): findings from a family-based association test (FBAT) analysis. Behav Brain Funct 4:48

131. Ogdie MN, Bakker SC, Fisher SE, Francks C, Yang MH, Cantor RM, Loo SK, van der Meulen E, Pearson P, Buitelaar J, Monaco A, Nelson SF, Sinke RJ, Smalley SL (2006) Pooled genome-wide linkage data on 424 ADHD ASPs suggests genetic heterogeneity and a common risk locus at 5p13. Mol Psychiatry 11:5-8

132. Plomin R, Davis OS (2009) The future of genetics in psychology and psychiatry: microarrays, genome-wide association, and noncoding RNA. J Child Psychol Psychiatry 50:63-71

133. Ponce G, Hoenicka J, Rubio G, Ampuero I, Jimenez-Arriero MA, Rodriguez-Jimenez R, Palomo T, Ramos JA (2003) Association between cannabinoid receptor gene (CNR1) and childhood attention deficit/hyperactivity disorder in Spanish male alcoholic patients. Mol Psychiatry 8:466-467

134. Psychiatric-GWAS-Consortium-Coordinating-Committee, Cichon S, Craddock N, Daly M, Faraone SV, Gejman PV, Kelsoe J, Lehner T, Levinson DF, Moran A, Sklar P, Sullivan PF (2009) Genomewide association studies: history, rationale, and prospects for psychiatric disorders. Am J Psychiatry 166:540-556

135. Qian Q, Wang Y, Li J, Yang L, Wang B, Zhou R, Glatt SJ, Faraone SV (2007) Evaluation of potential gene-gene interactions for attention deficit hyperactivity disorder in the Han Chinese population. Am J Med Genet B Neuropsychiatr Genet 144B:200-206

136. Qian QJ, Liu J, Wang YF, Yang L, Guan LL, Faraone SV (2009) Attention Deficit Hyperactivity Disorder comorbid oppositional defiant disorder and its predominately inattentive type: evidence for an association with COMT but not MAOA in a Chinese sample. Behav Brain Funct 5:8
137. Quist JF, Barr CL, Schachar R, Roberts W, Malone M, Tannock R, Basile VS, Beitchman J, Kennedy JL (2003) The serotonin 5HT1B receptor gene and attention deficit hyperactivity disorder. Mol Psychiatry 8:98-102

138. Reif A, Jacob CP, Rujescu D, Herterich S, Lang S, Gutknecht L, Baehne CG, Strobel A, Freitag CM, Giegling I, Romanos M, Hartmann A, Rosler M, Renner TJ, Fallgatter AJ, Retz W, Ehlis AC, Lesch KP (2009) Influence of functional variant of neuronal nitric oxide synthase on impulsive behaviors in humans. Arch Gen Psychiatry 66:41-50

139. Retz W, Freitag CM, Retz-Junginger P, Wenzler D, Schneider M, Kissling C, Thome J, Rosler M (2008) A functional serotonin transporter promoter gene polymorphism increases ADHD symptoms in delinquents: interaction with adverse childhood environment. Psychiatry Res 158:123-131

140. Retz W, Rosler M, Kissling C, Wiemann S, Hunnerkopf R, Coogan A, Thome J, Freitag C (2008) Norepinephrine transporter and catecholamine-O-methyltransferase gene variants and attention-deficit/hyperactivity disorder symptoms in adults. J Neural Transm 115:323-329

141. Rhodes SM, Coghill DR, Matthews K (2004) Methylphenidate restores visual memory, but not working memory function in attention deficit-hyperkinetic disorder. Psychopharmacology (Berl) 175:319-330

142. Rhodes SM, Coghill DR, Matthews K (2005) Neuropsychological functioning in stimulant-naive boys with hyperkinetic disorder. Psychol Med 35:1109-1120

143. Ribases M, Ramos-Quiroga JA, Hervas A, Bosch R, Bielsa A, Gastaminza X, Artigas J, Rodriguez-Ben S, Estivill X, Casas M, Cormand B, Bayes M (2007) Exploration of 19 serotoninergic candidate genes in adults and children with attention-deficit/ hyperactivity disorder identifies association for 5HT2A, DDC and MAOB. Mol Psychiatry

144. Risch N, Merikangas K (1996) The future of genetic studies of complex human diseases. Science 273:1516-1517

145. Roman T, Schmitz M, Polanczyk GV, Eizirik M, Rohde LA, Hutz MH (2002) Further evidence for the association between attention-deficit/hyperactivity disorder and the dopamine-betahydroxylase gene. Am J Med Genet 114:154-158

146. Romanos M, Freitag C, Jacob C, Craig DW, Dempfle A, Nguyen TT, Halperin R, Walitza S, Renner TJ, Seitz C, Romanos J, Palmason H, Reif A, Heine M, Windemuth-Kieselbach C, Vogler C, Sigmund J, Warnke A, Schafer H, Meyer J, Stephan DA, Lesch KP (2008) Genome-wide linkage analysis of ADHD using high-density SNP arrays: novel loci at 5q13.1 and 14q12. Mol Psychiatry 13:522-530

147. Rommelse N, Altink ME, Martin NC, Buschgens CJ, Faraone SV, Buitelaar JK, Sergeant JA, Oosterlaan J (2008) Relationship between endophenotype and phenotype in ADHD. Behav Brain Funct 4:4

148. Rommelse NN, Altink ME, Arias-Vasquez A, Buschgens CJ, Fliers E, Faraone SV, Buitelaar JK, Sergeant JA, Franke B, Oosterlaan J (2008) A review and analysis of the relationship between neuropsychological measures and DAT1 in ADHD. Am J Med Genet B Neuropsychiatr Genet 147B:1536-1546

149. Rommelse NN, Altink ME, Arias-Vasquez A, Buschgens CJ, Fliers E, Faraone SV, Buitelaar JK, Sergeant JA, Oosterlaan J, Franke B (2008) Differential association between MAOA, ADHD and neuropsychological functioning in boys and girls. Am J Med Genet B Neuropsychiatr Genet 147B:1524-1530

150. Rommelse NN, Arias-Vasquez A, Altink ME, Buschgens CJ, Fliers E, Asherson P, Faraone SV, Buitelaar JK, Sergeant JA, Oosterlaan J, Franke B (2008) Neuropsychological endophenotype approach to genome-wide linkage analysis identifies susceptibility loci for ADHD on 2q21.1 and 13q12.11. Am J Hum Genet 83:99-105 
151. Sanchez-Mora C, Ribases M, Ramos-Quiroga JA, Casas M, Bosch R, Boreatti-Hummer A, Heine M, Jacob CP, Lesch KP, Fasmer OB, Knappskog PM, Kooij JJ, Kan C, Buitelaar JK, Mick E, Asherson P, Faraone SV, Franke B, Johansson S, Haavik J, Reif A, Bayes M, Cormand B (2009) Meta-analysis of brain-derived neurotrophic factor p.Val66Met in adult ADHD in four European populations. Am J Med Genet B Neuropsychiatr Genet

152. Schmitz M, Denardin D, Silva TL, Pianca T, Roman T, Hutz MH, Faraone SV, Rohde LA (2006) Association between alpha2a-adrenergic receptor gene and ADHD inattentive type. Biol Psychiatry 60:1028-1033

153. Schuster SC (2008) Next-generation sequencing transforms today's biology. Nat Methods 5:16-18

154. Sebat J, Lakshmi B, Malhotra D, Troge J, Lese-Martin C, Walsh T, Yamrom B, Yoon S, Krasnitz A, Kendall J, Leotta A, Pai D, Zhang R, Lee YH, Hicks J, Spence SJ, Lee AT, Puura K, Lehtimaki T, Ledbetter D, Gregersen PK, Bregman J, Sutcliffe JS, Jobanputra V, Chung W, Warburton D, King MC, Skuse D, Geschwind DH, Gilliam TC, Ye K, Wigler M (2007) Strong association of de novo copy number mutations with autism. Science 316:445-449

155. Sengupta S, Grizenko N, Schmitz N, Schwartz G, Bellingham J, Polotskaia A, Stepanian MT, Goto Y, Grace AA, Joober R (2008) COMT Val108/158Met polymorphism and the modulation of task-oriented behavior in children with ADHD. Neuropsychopharmacology 33:3069-3077

156. Shaw P, Gornick M, Lerch J, Addington A, Seal J, Greenstein D, Sharp W, Evans A, Giedd JN, Castellanos FX, Rapoport JL (2007) Polymorphisms of the dopamine D4 receptor, clinical outcome, and cortical structure in attention-deficit/hyperactivity disorder. Arch Gen Psychiatry 64:921-931

157. Sheehan K, Lowe N, Kirley A, Mullins C, Fitzgerald M, Gill M, Hawi Z (2005) Tryptophan hydroxylase 2 (TPH2) gene variants associated with ADHD. Mol Psychiatry 10:944-949

158. Sklar P, Smoller JW, Fan J, Ferreira MA, Perlis RH, Chambert K, Nimgaonkar VL, McQueen MB, Faraone SV, Kirby A, de Bakker PI, Ogdie MN, Thase ME, Sachs GS, Todd-Brown K, Gabriel SB, Sougnez C, Gates C, Blumenstiel B, Defelice M, Ardlie KG, Franklin J, Muir WJ, McGhee KA, MacIntyre DJ, McLean A, VanBeck M, McQuillin A, Bass NJ, Robinson M, Lawrence J, Anjorin A, Curtis D, Scolnick EM, Daly MJ, Blackwood DH, Gurling HM, Purcell SM (2008) Whole-genome association study of bipolar disorder. Mol Psychiatry 13:558-569

159. Solanto MV (1998) Neuropsychopharmacological mechanisms of stimulant drug action in attention-deficit hyperactivity disorder: a review and integration. Behav Brain Res 94:127-152

160. Song EY, Paik KC, Kim HW, Lim MH (2009) Association between catechol-O-methyltransferase gene polymorphism and attention-deficit hyperactivity disorder in Korean population. Genet Test Mol Biomarkers 13:233-236

161. Sonuga-Barke EJ, Brookes KJ, Buitelaar J, Anney R, Bitsakou P, Baeyens D, Buschgens C, Chen W, Christiansen H, Eisenberg J, Kuntsi J, Manor I, Melia A, Mulligan A, Rommelse N, Muller UC, Uebel H, Banaschewski T, Ebstein R, Franke B, Gill M, Miranda A, Oades RD, Roeyers H, Rothenberger A, Sergeant J, Steinhausen HC, Thompson M, Taylor E, Asherson P, Faraone SV (2008) Intelligence in DSM-IV combined type attentiondeficit/hyperactivity disorder is not predicted by either dopamine receptor/transporter genes or other previously identified risk alleles for attention-deficit/hyperactivity disorder. Am J Med Genet B Neuropsychiatr Genet 147:316-319

162. Sonuga-Barke EJ, Lasky-Su J, Neale BM, Oades R, Chen W, Franke B, Buitelaar J, Banaschewski T, Ebstein R, Gill M, Anney R, Miranda A, Mulas F, Roeyers H, Rothenberger A,
Sergeant J, Steinhausen HC, Thompson M, Asherson P, Faraone SV (2008) Does parental expressed emotion moderate genetic effects in ADHD? An exploration using a genome wide association scan. Am J Med Genet B Neuropsychiatr Genet 147B:1359-1368

163. Sonuga-Barke EJ, Sergeant JA, Nigg J, Willcutt E (2008) Executive dysfunction and delay aversion in attention deficit hyperactivity disorder: nosologic and diagnostic implications. Child Adolesc Psychiatr Clin N Am 17:367-384 ix

164. Sullivan PF, Lin D, Tzeng JY, van den Oord E, Perkins D, Stroup TS, Wagner M, Lee S, Wright FA, Zou F, Liu W, Downing AM, Lieberman J, Close SL (2008) Genomewide association for schizophrenia in the CATIE study: results of stage 1. Mol Psychiatry 13:570-584

165. Swanson J, Oosterlaan J, Murias M, Schuck S, Flodman P, Spence MA, Wasdell M, Ding Y, Chi HC, Smith M, Mann M, Carlson C, Kennedy JL, Sergeant JA, Leung P, Zhang YP, Sadeh A, Chen C, Whalen CK, Babb KA, Moyzis R, Posner MI (2000) Attention deficit/hyperactivity disorder children with a 7repeat allele of the dopamine receptor D4 gene have extreme behavior but normal performance on critical neuropsychological tests of attention. Proc Natl Acad Sci USA 97:4754-4759

166. Swanson JM, Kinsbourne M, Nigg J, Lanphear B, Stefanatos GA, Volkow N, Taylor E, Casey BJ, Castellanos FX, Wadhwa PD (2007) Etiologic subtypes of attention-deficit/hyperactivity disorder: brain imaging, molecular genetic and environmental factors and the dopamine hypothesis. Neuropsychol Rev 17: 39-59

167. Szatmari P, Maziade M, Zwaigenbaum L, Merette C, Roy MA, Joober R, Palmour R (2007) Informative phenotypes for genetic studies of psychiatric disorders. Am J Med Genet B Neuropsychiatr Genet 144B:581-588

168. Szatmari P, Paterson AD, Zwaigenbaum L, Roberts W, Brian J, Liu XQ, Vincent JB, Skaug JL, Thompson AP, Senman L, Feuk L, Qian C, Bryson SE, Jones MB, Marshall CR, Scherer SW, Vieland VJ, Bartlett C, Mangin LV, Goedken R, Segre A, Pericak-Vance MA, Cuccaro ML, Gilbert JR, Wright HH, Abramson RK, Betancur C, Bourgeron T, Gillberg C, Leboyer M, Buxbaum JD, Davis KL, Hollander E, Silverman JM, Hallmayer J, Lotspeich L, Sutcliffe JS, Haines JL, Folstein SE, Piven J, Wassink TH, Sheffield V, Geschwind DH, Bucan M, Brown WT, Cantor RM, Constantino JN, Gilliam TC, Herbert M, Lajonchere C, Ledbetter DH, Lese-Martin C, Miller J, Nelson S, Samango-Sprouse CA, Spence S, State M, Tanzi RE, Coon H, Dawson G, Devlin B, Estes A, Flodman P, Klei L, McMahon WM, Minshew N, Munson J, Korvatska E, Rodier PM, Schellenberg GD, Smith M, Spence MA, Stodgell C, Tepper PG, Wijsman EM, Yu CE, Roge B, Mantoulan C, Wittemeyer K, Poustka A, Felder B, Klauck SM, Schuster C, Poustka F, Bolte S, Feineis-Matthews S, Herbrecht E, Schmotzer G, Tsiantis J, Papanikolaou K, Maestrini E, Bacchelli E, Blasi F, Carone S, Toma C, Van Engeland H, de Jonge M, Kemner C, Koop F, Langemeijer $M$ et al (2007) Mapping autism risk loci using genetic linkage and chromosomal rearrangements. Nat Genet 39:319-328

169. Szatmari P, White J, Merikangas KR (2007) The use of genetic epidemiology to guide classification in child and adult psychopathology. Int Rev Psychiatry 19:483-496

170. Terracciano A, Sanna S, Uda M, Deiana B, Usala G, Busonero F, Maschio A, Scally M, Patriciu N, Chen WM, Distel MA, Slagboom EP, Boomsma DI, Villafuerte S, Sliwerska E, Burmeister M, Amin N, Janssens AC, van Duijn CM, Schlessinger D, Abecasis GR, Costa PT Jr (2008) Genome-wide association scan for five major dimensions of personality. Mol Psychiatry

171. Thapar A, Langley K, Fowler T, Rice F, Turic D, Whittinger N, Aggleton J, Van den Bree M, Owen M, O’Donovan M (2005) 
Catechol O-methyltransferase gene variant and birth weight predict early-onset antisocial behavior in children with attention-deficit/hyperactivity disorder. Arch Gen Psychiatry 62:1275-1278

172. Thapar A, Langley K, O’Donovan M, Owen M (2006) Refining the attention deficit hyperactivity disorder phenotype for molecular genetic studies. Mol Psychiatry 11:714-720

173. Trikalinos TA, Karvouni A, Zintzaras E, Ylisaukko-oja T, Peltonen L, Jarvela I, Ioannidis JP (2006) A heterogeneity-based genome search meta-analysis for autism-spectrum disorders. Mol Psychiatry 11:29-36

174. Trikalinos TA, Ntzani EE, Contopoulos-Ioannidis DG, Ioannidis JP (2004) Establishment of genetic associations for complex diseases is independent of early study findings. Eur J Hum Genet 12:762-769

175. Uhl GR, Drgon T, Johnson C, Li CY, Contoreggi C, Hess J, Naiman D, Liu QR (2008) Molecular genetics of addiction and related heritable phenotypes: genome-wide association approaches identify "connectivity constellation" and drug target genes with pleiotropic effects. Ann N Y Acad Sci 1141:318-381

176. Uhl GR, Drgon T, Liu QR, Johnson C, Walther D, Komiyama T, Harano M, Sekine Y, Inada T, Ozaki N, Iyo M, Iwata N, Yamada M, Sora I, Chen CK, Liu HC, Ujike H, Lin SK (2008) Genome-wide association for methamphetamine dependence: convergent results from 2 samples. Arch Gen Psychiatry 65:345-355

177. VanNess SH, Owens MJ, Kilts CD (2005) The variable number of tandem repeats element in DAT1 regulates in vitro dopamine transporter density. BMC Genet 6:55

178. Vrijenhoek T, Buizer-Voskamp JE, van der Stelt I, Strengman E, Sabatti C, Geurts van Kessel A, Brunner HG, Ophoff RA, Veltman JA (2008) Recurrent CNVs disrupt three candidate genes in schizophrenia patients. Am J Hum Genet 83:504-510

179. Waldman ID (2005) Statistical approaches to complex phenotypes: evaluating neuropsychological endophenotypes for attention-deficit/hyperactivity disorder. Biol Psychiatry 57:1347-1356

180. Waldman ID, Gizer IR (2006) The genetics of attention deficit hyperactivity disorder. Clin Psychol Rev 26:396-432

181. Waldman ID, Nigg JT, Gizer IR, Park L, Rappley MD, Friderici $\mathrm{K}$ (2006) The adrenergic receptor alpha-2A gene (ADRA2A) and neuropsychological executive functions as putative endophenotypes for childhood ADHD. Cogn Affect Behav Neurosci 6:18-30

182. Walitza S, Renner TJ, Dempfle A, Konrad K, Wewetzer C, Halbach A, Herpertz-Dahlmann B, Remschmidt H, Smidt J, Linder M, Flierl L, Knolker U, Friedel S, Schafer H, Gross C, Hebebrand J, Warnke A, Lesch KP (2005) Transmission disequilibrium of polymorphic variants in the tryptophan hydroxylase-2 gene in attention-deficit/hyperactivity disorder. Mol Psychiatry 10:1126-1132

183. Walters JT, Owen MJ (2007) Endophenotypes in psychiatric genetics. Mol Psychiatry 12:886-890

184. Wang B, Wang Y, Zhou R, Li J, Qian Q, Yang L, Guan L, Faraone SV (2006) Possible association of the alpha-2A adrenergic receptor gene (ADRA2A) with symptoms of attention-deficit/hyperactivity disorder. Am J Med Genet B Neuropsychiatr Genet 141B:130-134

185. Wellcome-Trust-Case-Control-Consortium (2007) Genomewide association study of 14,000 cases of seven common diseases and 3,000 shared controls. Nature 447:661-678

186. Wermter A-K, Laucht M, Schimmelmann B, Banaschewski T, Sonuga-Barke E, Rietschel M, Becker K From Nature versus Nurture to Nature and Nurture: Gene $\times$ Environment Interactions in Mental Disorder-a selective review
187. Wigg KG, Takhar A, Ickowicz A, Tannock R, Kennedy JL, Pathare T, Malone M, Schachar R, Barr CL (2006) Gene for the serotonin transporter and ADHD: no association with two functional polymorphisms. Am J Med Genet B Neuropsychiatr Genet 141B:566-570

188. Xu X, Aysimi E, Anney R, Brookes K, Franke B, Zhou K, Buschgens C, Chen W, Christiansen H, Eisenberg J, Gabriels I, Manor I, Marco R, Muller UC, Mulligan A, Rommelse N, Thompson M, Uebel H, Banaschewski T, Buitelaar J, Ebstein R, Gill M, Miranda A, Mulas F, Oades RD, Roeyers H, Rothenberger A, Sergeant J, Sonuga-Barke E, Steinhausen HC, Taylor E, Faraone SV, Asherson P (2008) No association between two polymorphisms of the serotonin transporter gene and combined type attention deficit hyperactivity disorder. Am J Med Genet B Neuropsychiatr Genet

189. Xu X, Brookes K, Chen CK, Huang YS, Wu YY, Asherson P (2007) Association study between the monoamine oxidase A gene and attention deficit hyperactivity disorder in Taiwanese samples. BMC Psychiatry 7:10

190. Xu X, Brookes K, Sun B, Ilott N, Asherson P (2009) Investigation of the serotonin $2 \mathrm{C}$ receptor gene in attention deficit hyperactivity disorder in UK samples. BMC Res Notes 2:71

191. Xu X, Hawi Z, Brookes KJ, Anney R, Bellgrove M, Franke B, Barry E, Chen W, Kuntsi J, Banaschewski T, Buitelaar J, Ebstein R, Fitzgerald M, Miranda A, Oades RD, Roeyers H, Rothenberger A, Sergeant J, Sonuga-Barke E, Steinhausen HC, Faraone SV, Gill M, Asherson P (2008) Replication of a rare protective allele in the noradrenaline transporter gene and ADHD. Am J Med Genet B Neuropsychiatr Genet 147B:15641567

192. Xu X, Knight J, Brookes K, Mill J, Sham P, Craig I, Taylor E, Asherson P (2005) DNA pooling analysis of 21 norepinephrine transporter gene SNPs with attention deficit hyperactivity disorder: no evidence for association. Am J Med Genet B Neuropsychiatr Genet 134B:115-118

193. Xu X, Mill J, Sun B, Chen CK, Huang YS, Wu YY, Asherson P (2009) Association study of promoter polymorphisms at the dopamine transporter gene in Attention Deficit Hyperactivity Disorder. BMC Psychiatry 9:3

194. Yang JW, Jang WS, Hong SD, Ji YI, Kim DH, Park J, Kim SW, Joung YS (2008) A case-control association study of the polymorphism at the promoter region of the DRD4 gene in Korean boys with attention deficit-hyperactivity disorder: evidence of association with the $-521 \mathrm{C} / \mathrm{T}$ SNP. Prog Neuropsychopharmacol Biol Psychiatry 32:243-248

195. Zhou K, Chen W, Buitelaar J, Banaschewski T, Oades RD, Franke B, Sonuga-Barke E, Ebstein R, Eisenberg J, Gill M, Manor I, Miranda A, Mulas F, Roeyers H, Rothenberger A, Sergeant J, Steinhausen HC, Lasky-Su J, Taylor E, Brookes KJ, Xu X, Neale BM, Rijsdijk F, Thompson M, Asherson P, Faraone SV (2008) Genetic heterogeneity in ADHD: DAT1 gene only affects probands without CD. Am J Med Genet B Neuropsychiatr Genet 147B:1481-1487

196. Zhou K, Dempfle A, Arcos-Burgos M, Bakker SC, Banaschewski T, Biederman J, Buitelaar J, Castellanos FX, Doyle A, Ebstein RP, Ekholm J, Forabosco P, Franke B, Freitag C, Friedel S, Gill M, Hebebrand J, Hinney A, Jacob C, Lesch KP, Loo SK, Lopera F, McCracken JT, McGough JJ, Meyer J, Mick E, Miranda A, Muenke M, Mulas F, Nelson SF, Nguyen TT, Oades RD, Ogdie MN, Palacio JD, Pineda D, Reif A, Renner TJ, Roeyers H, Romanos M, Rothenberger A, Schafer H, Sergeant J, Sinke RJ, Smalley SL, Sonuga-Barke E, Steinhausen HC, van der Meulen E, Walitza S, Warnke A, Lewis CM, Faraone SV, Asherson P (2008) Meta-analysis of genome-wide linkage scans of attention deficit hyperactivity disorder. Am J Med Genet B Neuropsychiatr Genet 147B:1392-1398 